\title{
Voice and valency morphology in Äiwoo
}

\begin{abstract}
This paper describes the function and distribution of the main morphological markers of voice and valency in the Oceanic language Äiwoo: the undergoer-voice suffixes - $i$, -nyi(i), -ive, -eâ, and $-n \hat{a}$, and the circumstantial voice clitic $=\mathrm{C} \ddot{a}$. It compares these functions and distributions to those reconstructed for the Proto Oceanic transitivising morphemes $*_{-i}$ and $*_{\text {akin }}[\mathrm{i}]$, and suggests pathways of change that can account for many of the present-day Äiwoo forms as being reflexes of these morphemes and of the $3 \mathrm{SG}$ object clitic *=a, though some of the formal differentiation remains unexplained. This analysis implies that Äiwoo has a Philippine-type symmetrical voice system with Oceanic morphology, an unusual state of affairs which has implications for our understanding of the transition from Proto Malayo-Polynesian to Proto Oceanic.
\end{abstract}




\section{Voice and valency morphology in Äiwoo \\ Åshild Næss, University of Oslo}

\section{Introduction ${ }^{1}$}

The Oceanic language Äiwoo was argued by Næss (2015a) to have a symmetrical voice system, described as a "hybrid" of a Philippine-type and an Indonesian-type system. The same paper also suggested that the morphology involved in the voice system was largely compatible with the classification of Äiwoo as an Oceanic language proposed by Ross and Næss (2007); that is, it could largely be brought back to Proto Oceanic, a language for which the standard analysis assumes that symmetrical voice alternations had been lost.

The main goal of this paper is to provide a more detailed description of voice and valency-related morphology in Äiwoo than has previously been presented. I will describe a set of suffixes which are involved in voice marking and valency change, and the complex ways in which these forms are distributed across functions. I will point to parallels between some of these form/function distributions and those found in Philippine languages, further underscoring the common properties between Äiwoo and Philippine-type languages. I will also argue that the distribution and function of this set of forms closely parallel those reconstructed for the Proto Oceanic (POc) suffix $*-i$, and suggest that an origin in $*-i$ and in the POc 3 SG object clitic *=a goes a long way towards accounting for the present-day patterns, although some unresolved problems remain. Moreover, I will discuss in detail the distribution of the clitic $=\mathrm{C} \ddot{a}$, which was described as a circumstantial voice marker in Næss (2015a). The role of this clitic in the voice-marking system was the main reason this paper described the Äiwoo system as a Philippine-type/Indonesian-type hybrid, as the paper hypothesized $=\mathrm{C} \ddot{a}$ to be a reflex of the preposition *akən/*akin[i]; reflexes of this morpheme are found with applicative functions in Indonesian but not in Philippine languages. I will show that the distribution and functions of the Äiwoo clitic corresponds closely to those reconstructed for *akin[i] in Proto Oceanic, and propose a grammaticalisation path by which a preposition could plausibly have been reanalyzed as a voice marker.

On the basis of this description, I will argue that the best way to describe the system of voice and valency marking in Äiwoo is not so much as a Philippine-type/Indonesian-type hybrid but rather as a (simplified) Philippine-type system with Oceanic morphology. This raises obvious questions of how this situation has arisen, and I will propose some tentative answers to these questions. Any attempt at giving a historical account of Äiwoo morphology is fraught with uncertainty, because the current state of knowledge of the sound correspondences between Äiwoo and POc is extremely superficial (Ross and Næss 2007, Lackey and Boerger n.d.). More detailed comparative work between Äiwoo and its closest relatives, the languages of Santa Cruz, is urgently needed. For such comparative work to be possible, however, detailed descriptions of the systems of the individual languages are required, in order to identify possible cognate morphemes and structures for comparison. This paper thus attempts to lay the basis for further comparative work by providing a detailed description of the Äiwoo system, along with a number of hypotheses of how this system relates to those reconstructed for earlier historical stages, which in turn can be tested against data from related languages.

\footnotetext{
${ }^{1}$ The author would like to thank Bethwyn Evans and Malcolm Ross for helpful comments on earlier versions. The data on which this paper builds was collected during three field trips to Honiara and the Reef Islands in 2004, 2005 and 2015; the fieldwork was funded by the Norwegian Research Council, project number 148717 (2004-2005) and the Endangered Languages Documentation Programme, grant number SG0308 (2015).
} 
This paper is structured as follows. In section 2 I outline what is meant by symmetrical voice, and how the pattern of clausal organization found in canonical Oceanic languages differs from this. Section 3 presents the basics of Äiwoo verbal morphology before discussing the Äiwoo voice system and the reasons for classifying it as "Philippine-type". Sections 4 and 5 are the core of the paper: section 4 gives a detailed presentation of the distribution and functions of a cluster of suffixes associated with the undergoer voice, while section 5 does the same for the circumstantial voice clitic $=\mathrm{C} \ddot{a}$. Each section further compares the described distribution to that of a reconstructed POc transitive marker, $*_{-i}$ in section 4 and *akin[i] in section 5 , and shows that the functions of the Äiwoo forms closely parallel those constructed for the POc markers; section 4.6 moreover points to a number of parallels between the Äiwoo undergoer-voice suffix ive and the patient and locative voices in present-day Tagalog. Each section then proposes a pathway from the POc forms to the present-day Äiwoo system which can account for most of the Äiwoo forms, though some unresolved questions remain. Section 6 then discusses the implications of Äiwoo having a "Philippine-type system with Oceanic morphology" for our understanding of the development from Proto Malayo-Polynesian to Proto Oceanic, and underscores the need for further comparative work on the Reefs-Santa Cruz languages in order to further improve this understanding.

\section{Symmetrical voice vs transitive marking}

Proto Malayo-Polynesian (PMP) is reconstructed with a voice system very similar to that found in present-day languages of the Philippines. This is a system often referred to as "symmetrical voice" (e.g. Himmelmann 2005a, Foley 2008, Riesberg 2014), characterized by voice alternations which allow arguments of different semantic roles to take what I will loosely call subject function ${ }^{2}$, but where no one voice is clearly the basic form from which the others are derived. The following set of examples from Tagalog is often used to illustrate such a system ${ }^{3}$ :

Tagalog (Schachter 1976:494-95; glosses from Ross 2002:26)

\begin{tabular}{|c|c|c|c|c|c|c|c|c|c|c|}
\hline \multirow[t]{2}{*}{ a. } & $\begin{array}{l}\text { Mag-alis } \\
\text { AV-take.out }\end{array}$ & $\begin{array}{l}\text { ang } \\
\text { SPEC }\end{array}$ & $\begin{array}{l}\text { babae } \\
\text { woman }\end{array}$ & $\begin{array}{l}n g \\
\text { NPIV }\end{array}$ & $\begin{array}{l}\text { bigas } \\
\text { rice }\end{array}$ & $\begin{array}{l}s a \\
\text { LOC }\end{array}$ & $\begin{array}{l}\text { sako } \\
\text { sack }\end{array}$ & $\begin{array}{l}\text { para } \\
\text { for }\end{array}$ & $\begin{array}{l}s a \\
\text { LOC }\end{array}$ & $\begin{array}{l}\text { bata. } \\
\text { child }\end{array}$ \\
\hline & 'The woman $v$ & vill ta & e some $r$ & ice ol & of a/the & sack & $\mathrm{r}$ a/th & child.' & & \\
\hline \multirow[t]{2}{*}{ b. } & $\begin{array}{l}\text { A-alis-in } \\
\text { DUR-take.out-PV }\end{array}$ & $\begin{array}{l}n g \\
\text { GEN }\end{array}$ & $\begin{array}{l}\text { babae } \\
\text { woman }\end{array}$ & $\begin{array}{l}\text { ang } \\
\text { SPEC }\end{array}$ & $\begin{array}{l}\text { bigas } \\
\text { rice }\end{array}$ & $\begin{array}{l}s a \\
\text { LOC }\end{array}$ & $\begin{array}{l}\text { sako } \\
\text { sack }\end{array}$ & $\begin{array}{l}\text { para } \\
\text { for }\end{array}$ & $\begin{array}{l}s a \\
\text { LOC }\end{array}$ & $\begin{array}{l}\text { bata. } \\
\text { child }\end{array}$ \\
\hline & 'A/the woman & will & ke the ri & ice ou & of $\mathrm{a} /$ the & sack $\mathrm{f}$ & $\mathrm{ra}$ a/the & 'hild.' & & \\
\hline \multirow[t]{3}{*}{ c. } & A-alis-an & $n g$ & babae & $n g$ & bigas & ang & sako & para & $s a$ & \\
\hline & DUR-take.out-LV & GEN & woman & NPIV & rice & SPEC & sack & for & LOC & \\
\hline & ${ }^{\prime} \mathrm{A} /$ the woman & will & ke some & rice & ut of the & sack & $\mathrm{r} \mathrm{a} / \mathrm{th}$ & child.' & & \\
\hline \multirow[t]{2}{*}{ d. } & Ipag-alis & $n g$ & babae & $n g$ & bigas & sa & sako & ang & bata. & \\
\hline & CV-take.out & GEN & woman & NPIV & rice & LOC & sack & SPEC & child & \\
\hline
\end{tabular}

\footnotetext{
${ }^{2}$ There has been considerable debate in the literature regarding what, if anything, can be considered the subject in Philippine-type symmetrical voice languages in particular, see e.g. Schachter (1976, 1977), Kroeger (1993), Riesberg (2014).

${ }^{3}$ Abbreviations follow the Leipzig Glossing Rules where these apply. Additional abbreviations: APPR, apprehensive; AUG, augmented number; AV, actor voice; CV, circumstantial voice; DIR, directional; LV, locative voice; MIN, minimal number; MOD, modal particle; N3AUG, non-3rd person augmented; NPIV, nonpivot argument; OBL.PRO, oblique pro-form; PA, pluractional; PDIR, person directional; PREP, preposition; PV, patient voice; RED, reduplication; RL, realis; SPEC, specific; TR, transitive suffix; UA, unit-augmented number; UV, undergoer voice.
} 
The voice marking on the verb correlates with the semantic role of the argument marked with ang, which for present purposes can be understood as a nominative marker. Thus the form in a. is referred to as the actor voice because it is the actor argument that takes ang, the b. form is called the patient voice because the patient is the ang-marked argument, etc. The ang-marked argument in turn shows privileged behavior in the syntax, such as being the only argument accessible to relativization.

Among present-day Western Austronesian ${ }^{4}$ languages, two subtypes of symmetrical voice systems are identified, often referred to as "Philippine-type" vs. "Indonesian-type" (e.g. Himmelmann 2005a: 175). For the present purposes, the most relevant differences between the two are that Philippine-type languages contrast two or more nonactor voices, as shown for Tagalog in (1), and that the relation targeted by the voice marking on the verb is the only target of syntactic promotion. In other words, a peripheral participant can be made the "subject" by means of the appropriate voice marker, e.g. the locative voice for a location; but this is the only promotion mechanism available.

By contrast, Indonesian-type languages show a basic two-way alternation between an actor voice and an undergoer voice, and complement this with applicatives that can apply to both actor-voice and undergoer-voice verbs. In the actor voice, the actor remains the subject when an applicative is added, and the applicativized argument becomes a nonsubject core argument - an object. In the undergoer voice, on the other hand, the applicativized argument becomes the subject - or, from a different perspective, a peripheral argument can be made core by means of an applicative (2b) and then made a subject by means of the undergoer voice (2c):

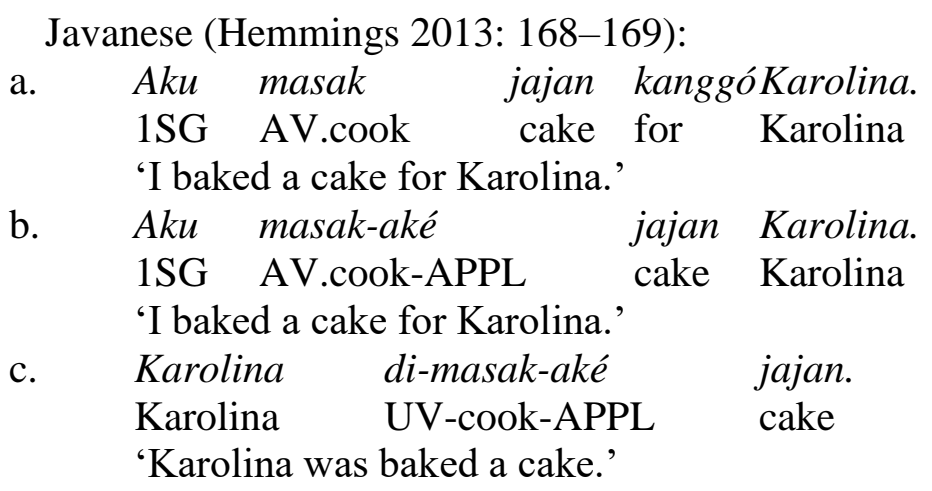

Thus Indonesian-type languages show two possible targets of syntactic promotion, which it seems reasonable to call a subject and an object relation, as opposed to the single target of promotion found in Philippine-type languages.

In contrast to the systems described above, Oceanic languages generally do not show voice alternations. Instead, they tend to formally mark verbs for transitivity, having one or two valency-increasing suffixes which add an object to an intransitive verb; these suffixes often combine with a marker of person and number of the object in question. In addition, they typically have preverbal markers of S and A arguments, meaning that Oceanic languages generally though not without exceptions - have clearly defined subject and object relations and accusative

\footnotetext{
4 'Western Austronesian' is a geographical rather than a genealogical term; as defined in Himmelmann (2002), it includes the Austronesian languages spoken in Taiwan, the Philippines, mainland southeast Asia, Western Indonesia (Sulawesi and all islands to the west of it), Borneo, and Madagascar, as well as Palauan and Chamorro.
} 
alignment. Example (3) illustrates this for Longgu (Solomon Islands), which has two transitive suffixes, $-\mathrm{Ci}(3 \mathrm{~b})$ and $-\mathrm{C} a$ 'ini (3c); the former introduces objects with a variety of roles such as location, cause, goal, and patient, while the latter is typically a displaced theme (Hill 1992: 53$60)$.

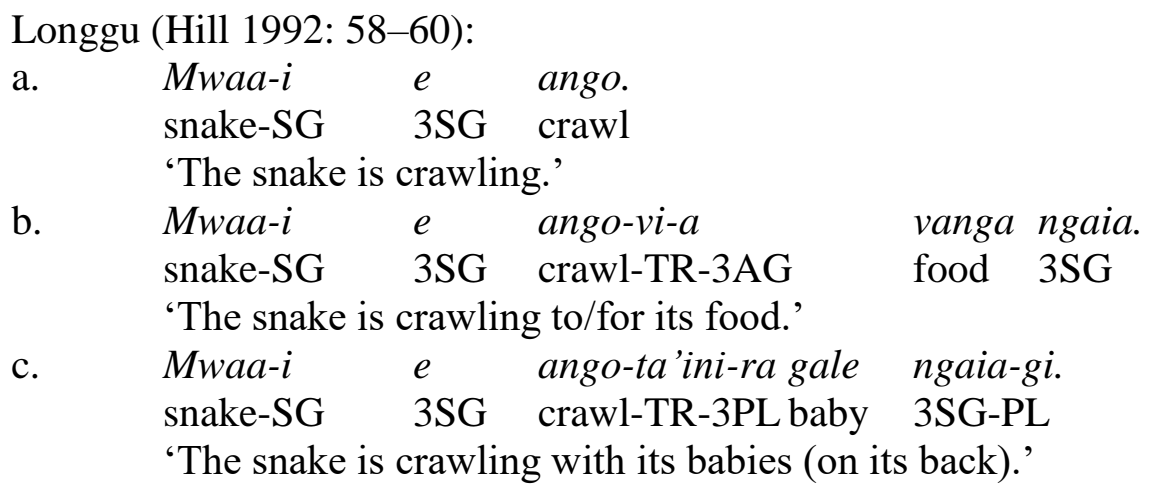

\section{Overview of the Äiwoo voice system}

3.1 ̈̈iwoo and its position in the Oceanic family tree

Äiwoo is spoken in the Reef Islands, a small island group in Solomon Islands' Temotu Province, as well as in settlements on nearby Santa Cruz Island and the national capital Honiara. The classification of Äiwoo as an Oceanic language is relatively recent, dating from Ross and Næss' (2007) proposal of a previously unrecognized first-order subgroup of Oceanic which they named "Temotu", as all its members are found within this province. The Temotu subgroup encompasses the Utupua-Vanikoro languages, which had long been recognized as Oceanic; but also the socalled Reefs-Santa Cruz (RSC) language group, which includes Äiwoo (sometimes called "Reefs" in the early literature, from the Reef Islands where it is mainly spoken) and the languages of Santa Cruz Island. The RSC languages had previously been argued by Wurm (e.g. 1978, 1981, 1985, 1987) not to be of clear Austronesian descent but to have a non-Austronesian or "Papuan" substrate. Ross and Næss argued that Wurm's typological arguments for a nonAustronesian substrate were flawed ${ }^{5}$, but also identified regular sound correspondences establishing Temotu as a first-order subgroup of Oceanic. They thus refuted the claims of a nonAustronesian substrate in Reefs-Santa Cruz.

The RSC languages are nevertheless unusual in a number of respects from an Oceanic perspective, showing, among other things, a highly complex verb structure, suffixed or encliticized person marking, and complex patterns of valency marking which to some extent continue earlier voice morphology. This is the case not just for the voice system in Äiwoo, which will be discussed below, but also for the passive and applicative alternations in the Santa Cruz language Nalögo, which appear to reflect PMP perfective undergoer voice $*<$ in $>$ and the dependent circumstantial voice suffix *-ani (van den Berg and Boerger 2011, Ross 2018). A better understanding of core aspects of RSC grammar is therefore likely to shed light on aspects

\footnotetext{
${ }^{5}$ Ross and Næss here referred mainly to Næss' (2006) refutation of Wurm's claim that Äiwoo showed noun class systems comparable to those found in some Papuan languages; Næss and Boerger (2008) later showed that Wurm's other main typological argument, the complexity of RSC verbal morphology, could similarly be accounted for in terms of an Oceanic origin. These results thus supported the argument of Lincoln (1978) that the RSC languages should be considered Austronesian despite their apparent anomalies.
} 
of the development from PMP to POc, and of Oceanic typology in general, which have so far received little attention.

3.2 Verbal morphology and basic clause structure

3.2.1 Tense, aspect and mood

Although it is possible for a verbal predicate in Äiwoo to consist of the verb root only, in most cases verbs show a fair degree of morphological complexity. A set of prefixes mark aspect and $\operatorname{mood}\left(i\right.$ - realis perfective; $k i$-/ $k u$ - realis imperfective; $n \ddot{a}-/ n \hat{a}^{-}{ }^{6}$ irrealis; $d e$ - apprehensive) and are largely obligatory on dynamic verbs; it is hypothesized that exceptions to this are phonologically conditioned and involve the elision of the perfective prefix $i$-in certain contexts (Roversi and Næss 2019: 326). Stative verbs do not normally occur with aspect/mood prefixes when describing an unchanging state, but may do so when referring to an actual or hypothetical change of state. In addition to the prefixes, aspect may be marked by the phasal-aspect clitics =to "now ${ }^{9}$, $=j o$ 'progressive', while the only apparent tense marker is the future clitic $=\mathrm{C} a a$; the latter can also have a habitual reading ${ }^{8}$. Some examples are shown in (4).

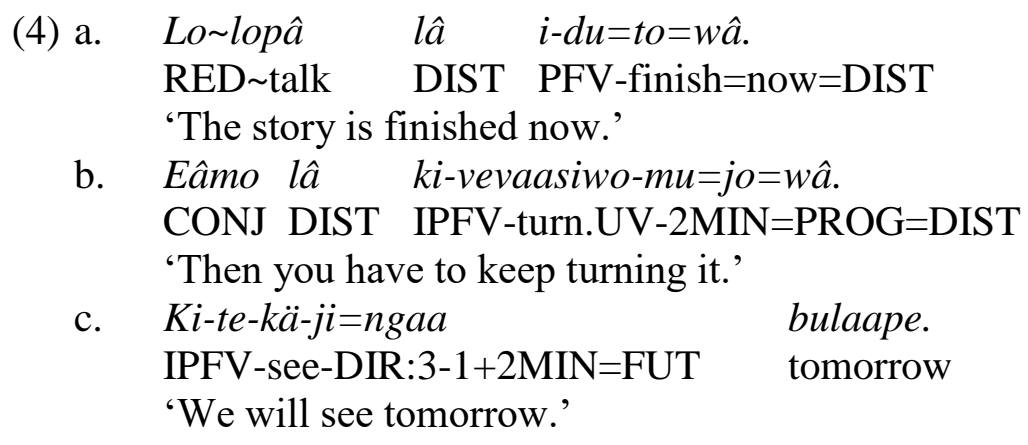

\subsubsection{Person marking}

As will be discussed further in 3.3 below, person marking depends on transitivity and voice; intransitive verbs and transitive actor-voice verbs take actor prefixes $(5 a-b)$, while transitive undergoer-voice verbs take actor suffixes (5c).
a. Li-ko-oli

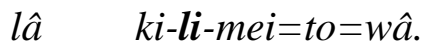
3AUG-lie-down DIST IPFV-3AUG-sleep=now=DIST
'They lay down and slept.'
b. Ilâkâ dä nии bulaape-mä
DIST some place next.day-DIR:1
li-pängä talâu wä nиu pevaio=kâ.
3AUG-eat.AVmeal of.3MIN place morning=DIST
'The next day, they ate breakfast.'

\footnotetext{
${ }^{6}$ The orthographic symbols $<\ddot{a}>$ and $<\hat{a}>$ are used for $[\mathfrak{a}]$ and $[a, p]$ respectively. These are clearly distinct phonemes, as seen by minimal pairs such as $l \ddot{a}$ 'other', lâ 'distal deictic particle'; but some morphemes show an alternation between the two conditioned by phonological properties of the following syllable.

${ }^{7}$ For discussion of the semantics of =to, see Roversi and Næss (2019: 338, 343-344).

${ }^{8}$ The habitual use of the future clitic is seen in examples $(12 \mathrm{a}, \mathrm{c})$.
} 


\section{c. Deu ko-mä olman=kä, nuduwo ki-ngä-i=lâ. before say-DIR: 1 old.man=CV wild.yam IPFV-eat.UV-3AUG=DIST 'In the old days, the old man told me, they ate wild yams.'}

The forms of the prefixes and suffixes are given in Tables 1-2. The person prefixes precede the aspect-mood prefixes on the verb, except with $3 \mathrm{AUG} l i-/ l u$-, which occur immediately before the verb root:
(6)
a. $\quad$ I-ki-mei.
1MIN-IPFV-sleep
'I am sleeping.'
b Mi-ki-mei.
2MIN-IPFV-sleep
c. Ki-li-mei.
'You are sleeping.'
IPFV-3AUG-sleep
'They are sleeping.'

The suffixes follow the verb stem and any directional suffixes, but precede enclitics, as seen e.g. in (7), (8), and (12).

Table 1: Actor prefixes

\begin{tabular}{|l|l|l|}
\hline & Minimal & Augmented \\
\hline 1 & i- & me- \\
\hline $1+2$ & ji- & de- \\
\hline 2 & mu-/mi- & mi- \\
\hline 3 & $\varnothing$ & li-/lu- \\
\hline
\end{tabular}

Table 2: Actor suffixes

\begin{tabular}{|l|l|l|}
\hline & Minimal & Augmented \\
\hline 1 & - no/-nee & - ngo(pu) \\
\hline $1+2$ & $-j i$ & $-d e$ \\
\hline 2 & $-m u$ & $-m i$ \\
\hline 3 & $\varnothing(-g u)$ & $-i$ \\
\hline
\end{tabular}

Two, partly interrelated, points are worth noting. Firstly, for certain combinations of person and number of the actor and undergoer argument, the undergoer may be marked by a suffix following the actor suffix in the undergoer voice, as in (7a). For person/number combinations not permitting such a sequence of suffixes, the undergoer argument is indicated by an independent 
pronoun (7b). Note that this pertains strictly to transitive undergoer-voice verbs; the actor voice does not appear to permit pronominal undergoers.

$\begin{array}{ll}\text { (7) a. } & \text { I-togulo-nee-mu=waa. } \\ & \text { PFV-hit.UV-1MIN-2MIN=FUT } \\ & \text { 'I will hit you.' } \\ \text { b. } & \text { I-togulu-mu=waa } \\ & \text { PFV-hit.UV-2MIN=FUT } \\ & \text { 'You will hit me.' }\end{array}$

Secondly, 3MIN actors are normally unmarked in both paradigms. The exception is when a $3 \mathrm{MIN}$ actor cooccurs with a non-3MIN undergoer in the undergoer voice; in such cases, the suffix - $g u$ appears followed by a suffix indicating the person and number of the undergoer, as in (8).

$$
\begin{array}{lll}
\text { Lâto } & i \text {-tu-gu-mu } & \text { iso-mu } \\
\text { thus } & \text { PFV-take-UV-3MIN-2MIN mother-2MIN } \\
\text { lâto } & i \text {-päi- } \boldsymbol{g} \boldsymbol{u}-\boldsymbol{m u}=\text { to=wâ. } \\
\text { this } & \text { PFV-throw.UV-3MIN-2MIN=now=DIST } \\
\text { 'So your mother took you and threw you out.' }
\end{array}
$$

It is possible to interpret this suffix - $g u$ as a marker of a $3 \mathrm{MIN}$ actor, and I have glossed it as such in this paper. Roversi (2019: 98-99), however, argues that the suffix does not in fact function as a person marker, but rather as a placeholder indicating that the following suffix is to be interpreted as referring to the undergoer rather than the actor. The precise analysis is of no particular relevance for the discussion in this paper; from a historical perspective, however, it is worth noting that $-g u$ presumably originates in the POc $1 \mathrm{SG}$ possessive form *gu (Ross and Næss 2007: 477), and that in certain specific contexts, notably in transitive imperatives, it indicates a $1 \mathrm{MIN}$ undergoer. The bridging context for the reanalysis is taken to be cases with a $3 \mathrm{MIN}$ actor and $1 \mathrm{MIN}$ undergoer.

Finally, note that the actor suffixes do not just occur with undergoer-voice roots but also on verbs marked with the circumstantial clitic $=\mathrm{C} \ddot{a}$ (see 3.2.3 and section 5); it is thus more accurate to say that the person suffixes appear in nonactor voices.

\subsubsection{Valency and clause structure}

There is no case marking of core arguments in Äiwoo. Actor and undergoer argument NPs are unmarked in both voices, while peripheral participants are marked by a preposition.

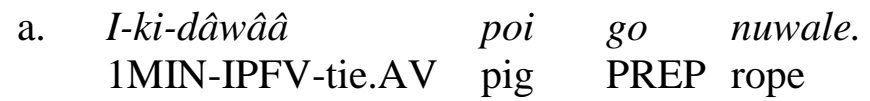

$$
\begin{aligned}
& \text { 'I tie up a/the pig(s) with rope.' }
\end{aligned}
$$

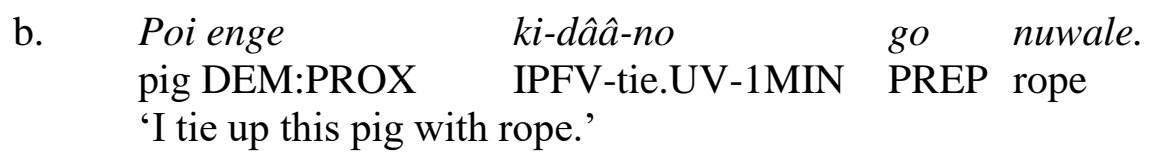


Äiwoo does not have underived ditransitive verbs; verbs which semantically involve three participants, such as lä̈̈lla 'give', encode the recipient argument in a prepositional phrase (10). However, the circumstantial-voice clitic $=\mathrm{C} \ddot{a}$, to be discussed in section 5, can derive constructions with three core arguments from transitive actor-voice or undergoer-voice verbs (11).

Sii i-la-kä go site.

fish PFV-give.UV-DIR:3 PREP woman's.sister.3MIN

'She gave the fish to her sister.'

$$
\begin{array}{lcc}
\text { Dee } & k u-w a \hat{a}-i-l e=n \ddot{a} & i u . \\
\text { this.thing } & \text { IPFV-forbid-3AUG-UA=CV } & \text { 1MIN } \\
\text { 'They have forbidden me this.' }
\end{array}
$$

Note that constructions with the circumstantial voice clitic always take actor suffixes, regardless of the transitivity and voice of the root; it can therefore be difficult to determine the voice of the root in examples like (11), as the verb wâa 'warn, forbid' is in fact not attested in my data without a circumstantial voice marker. I nevertheless include it here as it is a rare example of a clause with three arguments overtly expressed: the actor via the person/number suffixes on the verb, the thing forbidden or warned against with the initial pronoun dee 'this thing, this here', and the person to whom the warning is directed with the postverbal pronoun $i u$ ' $1 \mathrm{MIN}$ '. Peripheral participants may also be indicated by means of a directional suffix on the verb, as also seen for the recipient in (10); often a directional is the only indication of a peripheral participant

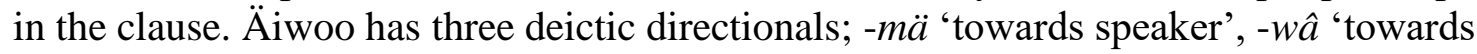
addressee', $-k \ddot{a}$ 'away from speaker and addressee, towards a 3rd person'. The directionals are very frequent not just on verbs describing physical motion, but on any predicate which can be interpreted as having a physical or metaphorical "direction" towards a participant; some examples with the 1st-person directional -mä are shown in (12).

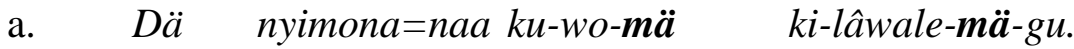

$$
\begin{aligned}
& \text { some time=FUT IPFV-go-DIR:1 IPFV-help-DIR:1-3MIN/1MIN } \\
& \text { 'Sometimes she comes and helps me.' }
\end{aligned}
$$

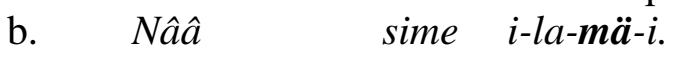

$$
\begin{aligned}
& \text { voice.3MIN person PFV-give.UV-DIR:1-3AUG } \\
& \text { 'They gave me word/news.' } \\
& \text { c. Pe-sibiliwââlili ilâ }=k \hat{a} \quad k i \text {-li-epave-m } \ddot{a}=k a a \\
& \text { people-young.woman DIST=DIST IPFV-3AUG-cook.AV-DIR:1=FUT } \\
& \text { de-ki-li-ngä. } \\
& \text { thing-IPFV-3AUG-eat.UV } \\
& \text { 'The young women will cook food for us.' }
\end{aligned}
$$

It does not, however, seem reasonable to analyze the directionals as person markers, both because they are not obligatory, and because they occur with reference to goal and recipient-type participants even with formally intransitive verbs, as in wo-mä 'come here [in my direction]' in (12a). For more discussion of the status and functions of directionals in Äiwoo, see Roversi (2019: 47), Næss (2018, to appear). 


\subsection{Voice vs transitivity}

The arguments for analyzing the Äiwoo system of clausal alternations as symmetrical voice, rather than a transitivity alternation, are summarized here (for a more detailed discussion, see Næss 2015a):

There are two types of two-participant verbs, referred to in 3.2 above as actor voice and undergoer voice, which enter into two different types of morphosyntactic structure. In the actor voice, unmarked word order is AVO and the actor argument is marked by prefixes on the verb (13a); in the undergoer voice, unmarked word order with full NP arguments is OVA and the actor argument is marked by suffixes (13b):
a. $\quad$ Pe-sime-engâ
li-epave $=$ to
sii $=k \hat{a}$.
PL-person-DEM:DIST
3AUG-cook.AV=now
fish $=$ DIST
'The people cooked fish.'
b. Sii lâ ki-epavi-i=to=wâ.
fish DIST IPFV-cook.UV-3AUG=now=DIST
'They cooked the fish.'

Note that, in contrast to (13b), pronominal $\mathrm{O}$ arguments of undergoer-voice clauses are systematically postverbal; see example (7b) and Næss (2015a: 291-293).

The actor-voice construction has formal similarities to intransitive clauses, in which word order is $\mathrm{SV}$ and $\mathrm{S}$ arguments are marked by the same set of prefixes as the A argument of actor-voice clauses, as shown in (14).

$$
\begin{array}{ll}
\begin{array}{l}
\text { Toponu } \\
\text { turtle }
\end{array} \quad \text { CONJ rat } \\
l \hat{a} \quad k i-l i-m o-l e=t o=w a \hat{a} . \\
\text { DIST } & \text { IPFV-3AUG-stay-UA=now=DIST } \\
\text { 'The turtle and the rat were staying together.' }
\end{array}
$$

However, apart from person marking being the same, there is no evidence that actor-voice clauses are formally intransitive. The $\mathrm{O}$ argument is not structurally incorporated; it is a phrasal constituent that can take various modifiers, including numerals, stative verbs, possessives, and relative clauses; and it appears outside of the verb phrase, as defined by a set of clitics taken to be VP-final (Næss 2015b) .

Moreover, the factors determining the choice between the two constructions do not correlate with generally recognized parameters of transitivity such as the degree of definiteness, individuation, or affectedness of the $\mathrm{O}$ argument. Rather, the choice appears to be determined by the relative prominence of clausal constituents in the discourse. This is seen in example (15), where the $\mathrm{O}$ argument is definite, high in topicality and equally affected in both cases; yet (15a) has actor voice, because the A argument is most prominent in the context (here, the focused argument,

\footnotetext{
${ }^{9}$ Note that there is in fact a tighter connection between the A argument in the undergoer voice and the verb, since this argument precedes the postverbal clitics; it is not unusual in Western Austronesian symmetrical voice languages for the verb to form a constituent with the postverbal non-VSA argument (Himmelmann 2005a: 142).
} 
which explains its clause-final position), whereas b. has undergoer voice ${ }^{10}$, as the $\mathrm{O}$ argument is more prominent than the A:

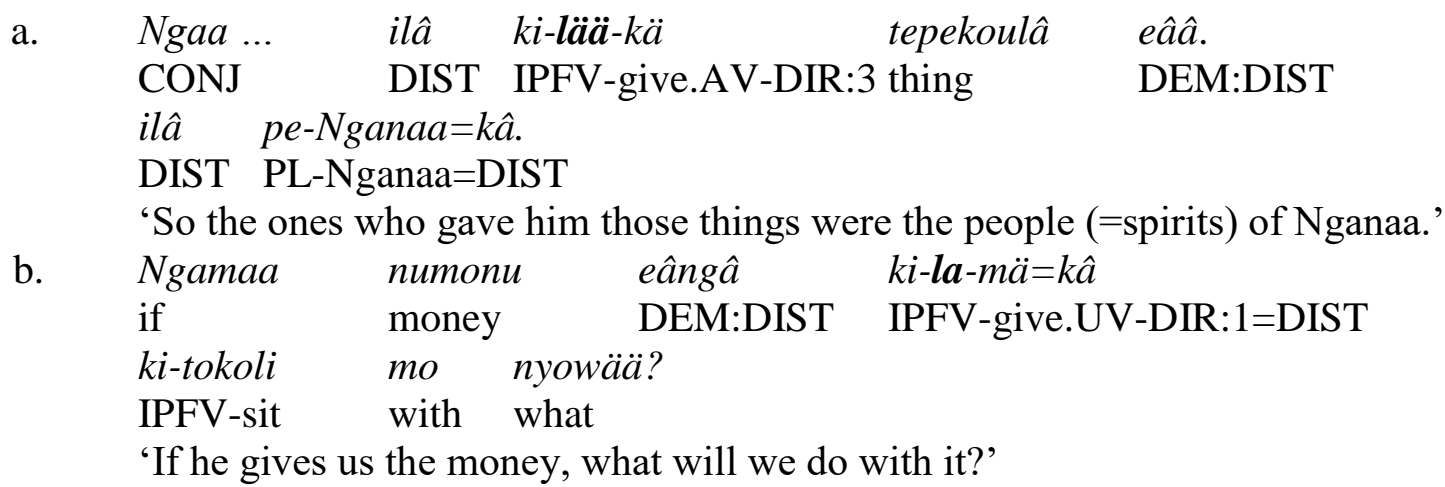

For a discussion of the term "prominent”, see Næss (2015a: 279-283). The relative prominence or salience of participants is a key factor in symmetrical voice systems in general; see eg. Naylor (1986) and Himmelmann (2005b) on Tagalog, Arka (2008) on eastern Indonesian languages, or Huang and Tanangkingsing (2011) on Formosan languages.

It may also be noted that the suffixes marking the actor argument in the undergoer voice (and the circumstantial voice, to be discussed in section 5) reflect POc possessive pronouns; this again patterns with Western Austronesian voice systems, where the actor in nonactor voices is marked by possessive forms. In sum, the system of clausal alternations in Äiwoo patterns like a symmetrical voice system rather than an Oceanic-type transitivity-based system.

\subsection{The Äiwoo system as "Philippine-type"}

The system in Äiwoo is structurally parallel to that described as "Philippine-type" above, in that there is only one target for syntactic promotion. I use here the term "voice-selected argument" (VSA) for the argument which is picked out by the voice form of the verb, i.e. the actor in the actor voice and the undergoer in the undergoer voice, rather than terms such as "subject" or "topic"; this is to avoid any implications as to which additional morphosyntactic properties this argument might show (see Næss 2015a, b for a discussion of VSA properties in Äiwoo). The most important formal characteristic of VSA status in Äiwoo is that it is the sole target of syntactic promotion (Næss 2015a: 297-298). Both core and peripheral arguments can be promoted to the status of VSA by means of a variety of mechanisms to be discussed below. However, it is not possible to promote a peripheral participant to non-voice-selected core status, i.e. to "object" position; that is, Äiwoo does not have canonical applicatives that turn peripheral participants into core arguments without simultaneously giving them "subject" status. Put somewhat differently, there is no derivational mechanism that adds an $\mathrm{O}$ argument to an intransitive verb and produces an actor-voice construction, as with (2b) above in Javanese. Instead, all derivational processes that add an $\mathrm{O}$ argument produce an undergoer-voice construction. This aligns with Philippine-type rather than Indonesian-type symmetrical-voice systems, since the latter combine two basic voices with one or more applicatives which can promote peripheral participants to object status, as described in section 2 .

\footnotetext{
${ }^{10}$ As both clauses have a 3MIN actor argument, which is typically unmarked, the difference in voice is here only shown through the difference in the form of the verb.
} 
On the other hand, rather than the typical Philippine-type set of 4-5 voices, Äiwoo has just two basic voice forms, an actor voice and an undergoer voice. As described above, verbs in the actor voice form clauses with basic AVO word order and take actor prefixes, whereas verbs in the undergoer voice form clauses with basic OVA word order and take actor suffixes. In addition to this basic two-way alternation, there is a circumstantial voice clitic $=\mathrm{C} \ddot{a}$, which patterns superficially like Indonesian applicatives in that it can be added both to actor-voice and undergoer-voice verb forms (Næss 2015a). Unlike with Indonesian applicatives, however, the addition of the circumstantial voice clitic essentially neutralizes the actor voice/undergoer voice distinction, in the sense that the outcome in both cases is a structure with actor suffixes and a circumstantial participant as the voice-selected argument. In (16a) below, the circumstantial participant is a location, while in (16b) it is, broadly speaking, an instrument; (16a) has the actorvoice form vei 'weave' while (16b) has the undergoer-voice form vili of the same verb. Without the clitic, vei would take an actor prefix whereas vili would take a suffix; but as can be seen from the examples, both forms take suffixes ( $-i$ ' $3 \mathrm{AUG}^{\prime}$ ' in a., $-n o$ ' $1 \mathrm{MIN}$ ' in b.) when $=\mathrm{C} \ddot{a}$ is added:

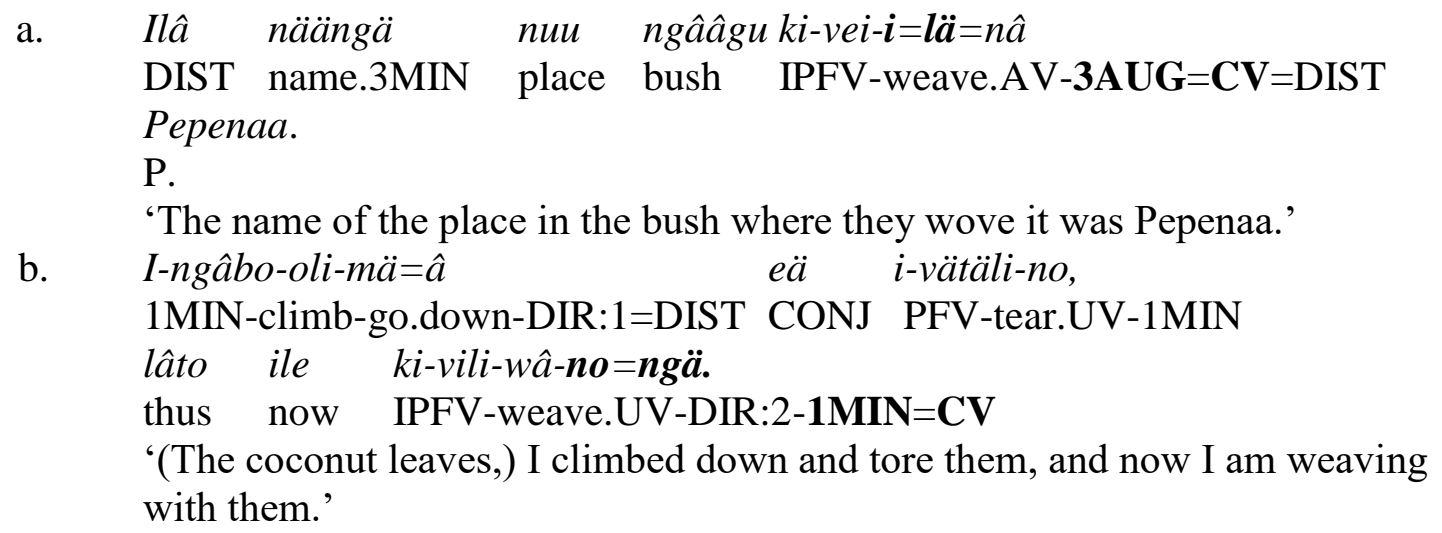

While the circumstantial voice clitic can appear on both transitive and intransitive verbs, intransitive verbs do not show a distinction between actor voice and undergoer voice. Most transitive verbs, on the other hand, have distinct actor-voice and undergoer-voice forms, which fall into a number of inflectional classes (Roversi 2019). Actor-voice and undergoer-voice morphology is not synchronically segmentable, and transitive verb roots do not occur without voice marking; the presentation in Table 3 below is meant to indicate the formal alternations between voice forms in the different classes rather than paradigms of affixal voice marking. In Table 3 I list what I consider to be the clearly identifiable inflectional classes with examples of verbs in actor-voice and undergoer-voice form; some additional minor patterns do exist. Class 1 is by far the largest, whereas classes 3-5 are represented in my data by only a handful of verbs each. 
Table 3: Voice inflection classes in Äiwoo

\begin{tabular}{|l|l|l|l|}
\hline Class & AV & UV & Example \\
\hline 1a & $-e$ & $-i$ & läve $\sim$ lävi 'fish with a net' \\
\hline $\mathbf{1 b}$ & $-e i /-o i$ & $-i$ & $g e i \sim g i$ 'rub, shave' \\
\hline $\mathbf{1 c}$ & $\varnothing$ & $-i$ & $e t a \sim e t a i$ 'fish with a line' \\
\hline $\mathbf{2 a}$ & $-o u$ & $-u$ & tou $\sim$ tu 'carry, bring, give birth to' \\
\hline $\mathbf{2 b}$ & $-\hat{a} w \hat{a} \hat{a}$ & $-\hat{a} \hat{a}$ & $e \hat{a} w \hat{a} \hat{a} \sim e \hat{a} \hat{a}$ 'pull' \\
\hline $\mathbf{2 c}$ & $-l o w e$ & $-l u$ & tâlowe tâlu 'cut long flexible object e.g. hair, grass' \\
\hline $\mathbf{3}$ & $-e i$ & $-(i) l i$ & vei $\sim$ vili 'weave' \\
\hline $\mathbf{4}$ & $\emptyset$ & $-(e) \hat{a}$ & välo $\sim$ väloeâa 'beckon, wave to signal someone' \\
\hline $\mathbf{5}$ & iive-/iivä- & $\varnothing$ & iivängo $\sim$ ngo 'twist or braid fibre into a rope' \\
\hline
\end{tabular}

A number of AV forms also have intransitive uses, and as such could be characterized as ambitransitives; the distinction is difficult to draw, however, since Äiwoo, like many Oceanic languages, allow arguments to lack overt expression when they are retrievable from context. For the two classes that show overt actor-voice morphology, namely class 2 and class $5^{11}$, Næss (2013) argues that the infixed -ou-/-âw-/-ow- in class 2 may be a reflex of the PMP actor-voice infix $*<u m>$. A tentative hypothesis for the class 5 prefix iive-/iivä-, which is attested with a handful of forms in my data, is that it may be a reflex of the PMP dependent actor-voice prefix *paN-, which was retained in a few verbs in POc (Lynch, Ross and Crowley 2002: 62). Äiwoo /v/ is a regular reflex of POc *p (Ross and Næss 2007: 463), and the actor-voice verb vängä 'eat' reflects POc *payan, which in turn reflects PMP *paN-ka?ən (Lynch, Ross and Crowley 2002: 62). Admittedly, the source of the initial $i i$-in the forms listed above remains to be explained; note that a similar structure is seen in the verbs iiee 'go up, step up, iiwoli 'go down, step down', iito 'go in, step in', iilâ 'go out, step out', which are used as independent motion verbs in contrast to ee, woli, to, lâ which occur as modifiers to verb stems, as well as in a handful of other verbs where a form without $i i$ - is not attested.

\section{The undergoer-voice cluster}

This section discusses a cluster of morphemes which show overlapping functions in the formation of undergoer-voice verbs. The forms involved are -i, -nyi(i), -ive, -(e) $\hat{a}$, and -nâ; I will refer to them in the following as undergoer-voice suffixes. In addition, I briefly discuss the causative prefix $(w) \hat{a}-/ v \ddot{a}$-, both because this prefix combines with a undergoer-voice suffix to form undergoer-voice causatives, and because forming causatives without the prefix is a marginal function of some of the undergoer-voice suffixes.

\subsection{Causatives}

Most causatives in Äiwoo are formed with the causative prefix ( $w) \hat{a}-/ v \ddot{a}-$, where the former allomorph is considerably more frequent than the latter. While reflexes of POc *p are generally lenited to v or w in Äiwoo (Ross and Næss 2007: 463), the unlenited form is retained in certain contexts, the most common of which is following the 3AUG prefix li-/lu-; compare $i$-ki-väng $\ddot{a}$ $1 \mathrm{MIN}-I P F V$-eat.AV 'I eat' with ki-li-päng ä IPFV-3AUG-eat.AV 'they eat' (see also example

\footnotetext{
${ }^{11}$ Class 3, which contrasts actor-voice forms in -ei with undergoer-voice forms in -(i)li, has a very small number of attested members (vei-vili 'weave', kei-kili 'dig', lei-li 'grate'), and I have nothing further to say about it at this point.
} 
5b), where vängä/pängä reflects POc *payan (Ross and Næss 2007: 482). The causative prefix similarly shows allomorphs $p(w) \hat{a}-/ p \ddot{a}$-following the $3 \mathrm{AUG}$ prefix.

The causative prefix occurs with intransitive base predicates (including nominal predicates as well as intransitive verb roots). In most cases ${ }^{12}$, the outcome is a transitive actor-voice verb (17b); in order to produce an undergoer-voice causative, a suffix must be added. In the vast majority of cases, this suffix has the form $-e \hat{a} /-w \hat{a} /-n \hat{a}(17 \mathrm{c})$, though a number of other options are attested and will be discussed in 4.4:
a. $\quad L i-n u b o-d u=t o=w \hat{a}$.
3AUG-die-all=now=DIST
'They are all dead.'
b. Lu-pwâ-nubo sii.
3AUG-CAUS-die fish
'They killed fish (actor voice).'
c. Dengaa i-te-wâ-i iumu,
lest PFV-see-DIR:2-3AUG 2MIN
lâto $\quad k u-\boldsymbol{w} \hat{\boldsymbol{a}}-n u b o-\boldsymbol{w} \hat{\boldsymbol{a}}-\boldsymbol{i} \quad$ iumu$=w \hat{a}$.
thus IPFV-CAUS-die-UV-3AUG 2MIN=DIST
'If they see you, they will kill you (undergoer voice).'

Without $w \hat{a}^{-}$, the suffix -ive forms undergoer-voice causatives of a few patientive intransitive verbs:
a. Ku-lu-pwä
IPFV-3AUG-go
mo $\quad l \hat{a}$
lâ
CONJ DEIC:DIST
ngä numoleaa
LOC between
nuwopa $=k \hat{a}$
ki-olo-ive
house $=$ DIST
$n \hat{a} \hat{a}-i=l \hat{a}$.
'They went between the houses and spread the word (lit. made their voices big).'
b. Ilâ ki-dali-ive $=j o=w \hat{a}$.
DIST IPFV-be.in.pain-UV=PROG=DIST
'It would make (the victim) feel a lot of pain.'

Eolo 'be big' (18a) is also attested with a causative in $-i$ :

$$
\begin{array}{ll}
\text { Ku-lu-mo-bakisi=to=wâ} & m o \\
\text { IPFV-3AUG-PA-run=now=DIST } & \text { CONJ } \\
l \hat{a} \quad k i-o l o-i=k e & n \hat{a} \hat{a}-i=l \hat{a} . \\
\text { DIST IPFV-be.big-UV=PROX } & \text { voice-3AUG=DIST } \\
\text { 'And they were running around and shouting (lit. making their voices big).' }
\end{array}
$$

The clitic $=\mathrm{C} \ddot{a}$ also has a causative function in a few cases; this will be discussed further in 5.1.

\footnotetext{
${ }^{12}$ Wâ-causatives of nominal predicates are often intransitives, as in wâ-meloo 'make peace'. Some causatives of statives function as adverbs, as in wâ-ponu 'last, final', from ponu 'after'. A few wâ-causatives take a prepositional complement, as in wâ-une CAUS-be.true 'agree to', where the thing agreed to is expressed in a prepositional phrase with the preposition go.
} 
4.2 Deriving undergoer-voice equivalents to transitive actor-voice forms As can be seen from Table 3, for the verbs that show the actor voice-undergoer voice alternation, the ones overtly marked for undergoer voice take either a final $-i$ (by far the most frequent) or a final -(e)â. This excludes the $-e i /-(i) l i$ alternation for which I have too few examples to say anything further. As discussed in 3.4 above, I analyze the Class 2 verbs as showing an infix in the actor voice, at least from a diachronic perspective, i.e. as being overtly marked for actor voice rather than for undergoer voice.

4.3 Deriving undergoer-voice transitives from intransitive verbs

While 4.2 discussed undergoer-voice forms which alternate with a transitive actor-voice form, the undergoer-voice suffixes are also found deriving undergoer-voice transitives from intransitive verbs. The main suffixes found in this function are $-i$ and $-i v e$, with a few attested examples of $-(e) \hat{a}$.

When used to derive transitive UV forms from intransitives, $-i$ typically has a comitative function; that is, it introduces a participant which is accompanied by the actor or moved by the action performed by the actor. As may be expected, this function is found mainly with verbs of motion and position.

The outcome of suffixing $-i$ to an intransitive verb stem is an undergoer-voice transitive, as can be seen by the fact that the derived forms take actor suffixes; compare (20b), where luwo- $i$ 'rush with' takes suffixes $-g u-i$ ' $3 \mathrm{MIN}-3 \mathrm{AUG}$ ', with (21), where luwo 'rush' is intransitive and lacks overt person marking (because the actor is $3 \mathrm{MIN}$ ), while the goal argument is indicated with a directional (cf. 3.2.3 above). In other words, the concomitant is the voice-selected argument in this construction.

$$
\begin{aligned}
& \text { a. Nâ-wâ-ki-ee-mi iu ngä tepukei } \\
& \text { IRR-CAUS-IPFV-go.up-2AUG 1MIN LOC canoe } \\
& \text { lâto ki-eâ-i-mi iu=ngâ wâluwo=kâ. } \\
& \text { thus IPFV-paddle-COM-2AUG } 1 \mathrm{MIN}=\mathrm{DIST} \text { middle=DIST } \\
& \text { 'Put } m e \text { in the canoe and paddle me to the middle (of the lagoon).' } \\
& \text { b. I-luwo-i-lâ-gu-i-le } \\
& \text { PFV-rush-COM-go.out-3MIN-3AUG-UA } \\
& \text { le ki-pi-gu-i-le=ne. } \\
& \text { PROX IPFV-bring.UV-3MIN-3AUG-UA=PROX }
\end{aligned}
$$$$
\text { 'She rushed out with (= carrying) them and took them with her.' }
$$

$$
\begin{array}{lll}
\text { I-luwo-kä } & k \ddot{a}=n \ddot{a} & k i \text {-siwo-gu-i-le. } \\
\text { PFV-rush-DIR:3 } & \text { say=CV } & \text { IPFV-hold.UV-3MIN-3AUG-UA } \\
\text { 'She rushed at them and tried to grab them.' }
\end{array}
$$

The suffix -ive shows the same formal properties, i.e. it derives undergoer-voice transitives from intransitive verbs; but the range of argument roles it introduces is much wider. These roles generally fall into the class that would typically be encoded as an object in a language with a clear subject/object distinction: patient or theme (vetäng ä 'be destructive' - vetängä-ive 'destroy', mâtâlâ 'be ready' - mâtâlâ-ive 'prepare'), stimulus of psych verbs (giââ 'be happy' giâa-ive 'be happy about, celebrate', sââ 'be proud' - sââ-ive 'be proud of'), content of speech 
verbs (lopâ 'talk' - lopâ-ive 'tell', ngoduwâ 'shout' - ngoduwâ-ive 'shout about', woulaa 'argue' - woulaa-ive 'argue about'). Some examples are given in (22)

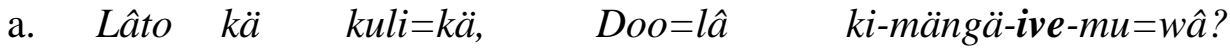 thus say $\operatorname{dog}=\mathrm{CV} \quad$ what=DIST IPFV-laugh-UV-2MIN=DIST 'The dog said, What are you laughing at?'
b. Kâ-no=ngä nâ-lopâ-ive-wâ-no=nge say-1MIN=CV IRR-speak-UV-DIR:2-1MIN=PROX
naae wä tepekâ mo vili.
story of.3MIN flying.fox CONJ parrot
'Now I want to tell you the story about the flying fox and the parrot.'
c. Pole nugu-mi-le ki-vävinäi mana, work POSS:TOOL-2MIN-UA IPFV-nice very
'Your work is very good, and we are proud of it'.

I have one example of -ive introducing a beneficiary participant, from a hymn used in church:
Lâ i-nubo-ive-gu.
DIST PFV-die-UV-3MIN/1MIN
'He died for me.'

Although concomitant arguments are usually introduced by $-i$, in a few attested cases -ive also introduces a concomitant, including one with a verb also attested with - $i$, namely ko 'lie' (24b):

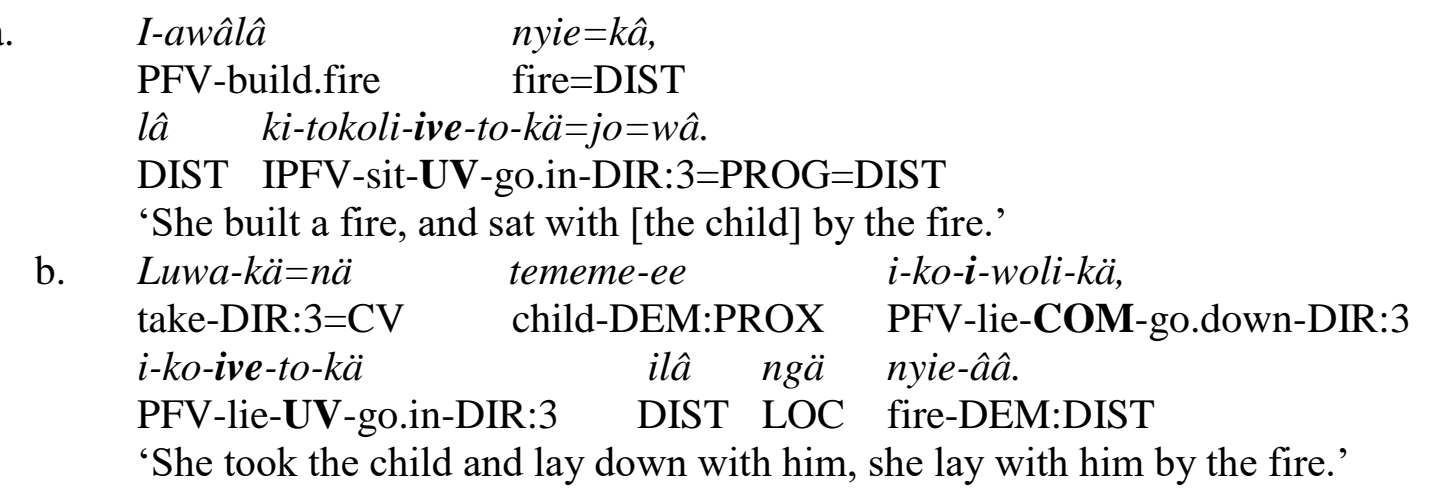

One verb, mâtâla 'be ready, get ready', has two attested UV forms, one with - $i$ and one with -ive, with a patient rather than a concomitant argument added in both cases:
a. Silingi nugo
string POSS:T
i-mâtâlâ-ive-no=ngâ.
string POSS:TOOL PFV-prepare-UV-1MIN=DIST
'I prepared my [fishing] lines.'
b. Eâmo mäjä le ku-mâtäläi-eopu-no=nge.
CONJ other PROX IPFV-prepare.UV-also-1MIN=PROX
'And I also prepared another one.'


mâtâlâ has both intransitive and transitive actor-voice uses, and it is possible that the $-i$ form corresponds to the actor-voice transitive while the -ive form is based on the intransitive; though the distinction seems difficult to draw in practice. Note that the two examples in (25) come from the same speaker and the same text.

I only have attested a small handful of clear examples of - (e) $\hat{a}$ deriving a UV transitive from an intransitive root. This means that I cannot generalize over the types of roles it may introduce, but it seems more likely to pattern with -ive than with - $i$; compare e.g. mibia 'be shy, be ashamed' mibiââ 'be ashamed of' to sââ 'be proud' - saaive 'be proud of'. Note, however, that -ive and $e \hat{a}$ appear to contrast in the following examples with the verb basiki 'run', where -ive introduces a concomitant argument and -êa a goal:

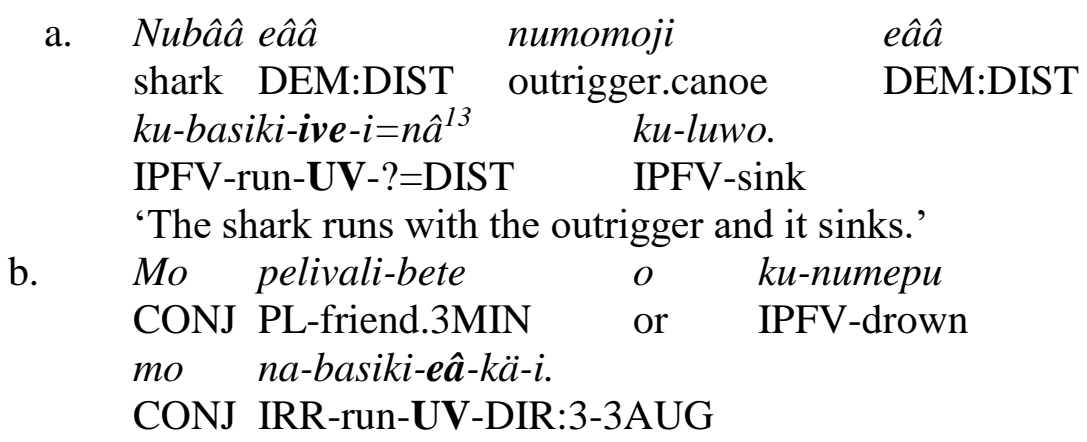

'And if a friend is drowning, they run to him.'

A single, rather complex, example suggests that the suffix -nyi(i), which is more commonly found following intransitive modifiers to undergoer-voice stems (4.5) can also function to derive undergoer-voice transitives from intransitives. In example (27a), the complex stem wo-âpa 'go past' consists of two intransitive roots, wo 'go' and âpa 'pass'; the object passed may be expressed in a prepositional phrase (ngämi is a pro-form for prepositional phrases with the locative preposition $n g \ddot{a})$. (27b) shows a slightly different structure, with the initial verb iipo 'step' rather than wo 'go', and this is the only example I have of this form in my corpus; however, a number of formally and semantically parallel forms such as iiwoli 'step down', iito 'step inside' are intransitive, and I therefore assume that the same is the case for iipo. However, (27b) as a whole is an undergoer-voice transitive, as shown by the person suffix; it would thus seem that the addition of -nyi here derives an undergoer-voice transitive from a basic intransitive form. Note that the adverb mana 'very' in turn takes $-i$, as expected when this form modifies an undergoer-voice stem:
a. De-ku-wo-âpa $=$ to
1+2AUG-IPFV-go-pass=now
ngämi.
'We have gone past it.'
b. Go ilâkâ iipo-âpa-nyi-mana-i-de=to.
because DIST step-pass-UV-very-UV-1+2AUG=now
'Because we have gone past it/stepped over it.'

\footnotetext{
${ }^{13}$ It is not clear to me why an -i appears following -ive in this example. It is unlikely to be the 3AUG actor suffix, as actor marking on comitative-marked verbs normally does not include the concomitant when the latter is inanimate, cf. example (35).
} 
The clitic $=\mathrm{C} \ddot{a}$ applies to both transitive and intransitive verbs and introduces arguments of a variety of peripheral roles such as location, instrument, manner etc. It will be discussed further in section 5 below.

The function of adding an undergoer argument to an intransitive verb closely resembles what is usually known as an applicative, defined by Peterson (2007: 1) as a construction that "allow[s] the coding of a thematically peripheral argument or adjunct as a core-object argument".

However, as already discussed in 3.4, it is not possible in Äiwoo to promote an argument to "object" function; the voice-selected argument is the only possible target of syntactic promotion. The construction discussed in this section thus differs from a canonical applicative in that the undergoer argument is introduced in "subject" rather than "object" function; Zúñiga and Kittilä (2019) call this function "subjective undergoer nucleative" or "subjective applicative".

\subsection{Deriving undergoer-voice causatives from actor-voice $w \hat{a}$-causatives}

As described in 4.1, adding the causative prefix $w \hat{a}-/ v \ddot{a}$ - to an intransitive verb normally results in a transitive actor-voice form. In order to produce an undergoer-voice causative, a suffix must be added to the prefixed forms ${ }^{14}$.

By far the most common suffix found in this function is $-(e) \hat{a}$ (and its phonological alternant $w \hat{a})$, as illustrated in (16) and (27):
a. Wâ-mapo-êa-päko-i-ngopu=waa=kâ.
CAUS-be.dry-UV-be.good-UV-1AUG=FUT=DIST
'We dry it well.'
b. I-wâ-mâlu-êa äi.
PFV-CAUS-stop-UV church
'The church put a stop to it.'

A small number of verbs show an alternant form -nâ in causatives; attested in my data are boki 'break, snap', eali 'be clear, be uncovered', emo 'begin', naapo 'lure', pole 'work', pu 'go'15, tepeu 'be stupid' (a borrowing from Vaeakau-Taumako, the Polynesian Outlier spoken in the Outer Reef Islands), uubo 'be forgotten', uuko 'be holy', waabo, be tame, be idle', wabou 'be holy, be taboo', wee 'go up'. There are no obvious phonological conditions on this form, and it thus seems to be lexically determined.
a. Ile ku-wâ-pole-nâ-gu-i=lâ
PROX IPFV-CAUS-work-UV-3MIN-3AUG=DIST
ile nuwosi nime li-eve ee.
PROX kind of.3MIN person 3AUG-three PROX
'He gives instructions to (lit. makes work) these three kinds of people.'
b. De-wâ-tepeu-nâ-mu=io iu!
APPR-CAUS-be.stupid-UV-2MIN=PROH $1 \mathrm{MIN}$
'Don't make a fool of me!'

\footnotetext{
${ }^{14}$ There are certain exceptions to this, the most important being the derivation of verbs of placement from verbs of motion, e.g. woli 'go down', wâ-ku-woli 'put down(UV)'. It is interesting to note that the directional verbs which enter into this construction ( $e$ e 'go up', woli 'go down', to 'go in', lâ 'go out') do not take undergoer-voice marking when modifying an undergoer-voice stem either (4.5).

${ }^{15}$ In the form wâpunâ 'feed', lit. 'cause to go'. I have another apparent example of $p u$ in a causative construction with the suffix $-w \hat{a}$, which seems to have the literal motion meaning.
} 
The other suffixes discussed in this section are also attested in this function, but only sporadically. (30) shows -ive in this function:
Doo ku-wo-waa-mä mo siwe
what IPFV-go-?-DIR:1 with sister.3MIN
ku-wâ-buläng ä-ive-mä-i-le
ngä ny-ee?
IPFV-CAUS-be.dirty-UV-DIR:1-3AUG-UA LOC place-DEM:PROX
'Why did he and his sister come and make this place dirty?'

For - $i$ I have two examples with the root иири '(be) together'; it is not entirely clear to me whether this is best seen as a variant form of eopu 'also, too, together', which occurs most frequently as an adverb, or as a distinct verbal root (cf. also vââpu 'assemble, get together').

a.

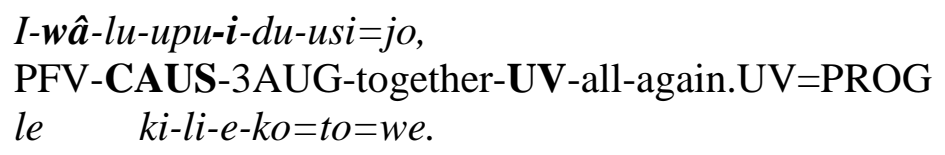

I-wâ-lu-upu-i-du-usi=jo,

PFV-CAUS-3AUG-together-UV-all-again.UV=PROG

le $\quad k i-l i-e-k o=t o=w e$.

PROX IPFV-3AUG-PA-lie=now=PROX

'He put them all together, and they lay there.'

b. I-wâ-lu-upu-i-gu-i-le

PFV-CAUS-3AUG-together-UV-3MIN-3AUG-UA

ilâ namaa le lile.

DIST MOD PROX marry

'The two of them are joined together by this marriage.'

This structure is unusual in that it shows the 3AUG prefix $l u$-following the causative prefix; in most cases, prefixal person marking precedes the causative. The order $w \hat{a}-l u$ - is otherwise characteristic of placement verbs formed by causativization of directional verbs, when these have a plural undergoer (31a); note that these do not take an undergoer suffix (cf. footnote 14). I also have an example of a causative with uирu showing no suffix, and thus patterning with the directional verbs on this point as well (32b) :
a. Teväivä
ile $\quad k u-w \hat{a}-l u-w o l i-n o=t o=w a ̂$.
stone
PROX IPFV-CAUS-3AUG-go.down-1MIN=now=DIST 'I put the stones down.'
b. Lamaa la $\quad i$-wâ-lu-upu-gu-i=lâ.
MOD DIST PFV-CAUS-3AUG-together-3MIN-3AUG=DIST
'That is how he puts them together.'

Finally, a couple of examples suggest that the suffix -nyi $i$, which will be discussed further in 4.5 below, can also function as an UV suffix in $w \hat{a}$-causatives. The first example involves the form wopanäbenyii 'to line up in a row', said of a group of women hiding in the bush, and is analyzable as wo-pâ-näbe-nyi-i 'go-CAUS-be.in.a.line-UV-3AUG'; the appearance of the unlenited form $p \hat{a}-$ of the causative prefix is due to this form appearing in second position of a complex stem, following the intransitive verb root wo 'go'. The second is a form for which I am unsure of the exact meaning, but which looks formally like a causative: väwalenyi which may be analyzable as CAUS-root-nyi, though the meaning of the root is unclear. 
4.5 Following intransitive modifiers to undergoer-voice stems Äiwoo allows a verb to modify another in a nuclear-layer serial verb construction, a common construction in Oceanic languages (Crowley 2002, Næss and Boerger 2008). When an undergoer-voice verb is modified by an intransitive verb in such a construction, the latter takes a suffix $-i$ or $-n y i(i)^{16}$. Thus in (33a), lopa 'speak' is an intransitive verb, and the V2 päko 'be good', also an intransitive verb, takes no further marking. In (33b), however, lobâku 'fold' is an undergoer-voice transitive, and päko as V2 takes the suffix $-i$.
a. Ki-lo lopâ-päko-mana=to.
IPFV-RED speak-be.good-very=now
'(The child) could speak very well.'
b. I-lo lobâku-päko-i-kä.
PFV-RED fold.UV-be.good-UV-DIR:3
'Fold it properly.'

If there are several intransitive verbs or manner adverbs ${ }^{17}$ modifying an undergoer-voice stem in a single complex form, the suffix is repeated. Example (34) shows that both päko 'be good' and mana 'very' take the suffix $-i$ when both occur modifying the undergoer-voice verb kä̈̈ 'know' in a single construction:

\section{I-kä̈̈-päko-i-mana-i-no. \\ PFV-know.UV-be.good-UV-very-UV-1MIN \\ 'I know it very well.'}

(35) appears to show $-i$ on three consecutive modifiers; it should be noted, however, that the status of the final vowel sequence, realized phonetically as a long $-i$, is somewhat uncertain, especially given the following $3 \mathrm{AUG}$ pronoun which can also have the form ijii:

$$
\begin{array}{ll}
\text { Ki-amole-wâtu-i-päko-i-mana-i-i } & j i i=l e . \\
\text { IPFV-see-go.far-UV-be.good-UV-very-UV-3AUG } & \text { 3AUG=PROX } \\
\text { 'They have to look after them extra well.' } &
\end{array}
$$

Example (36) shows that $-i$ in the undergoer-voice agreement function and in the comitative function described in 4.3 may cooccur. Here, the intransitive verb $e \hat{a}$ 'paddle' is made into an undergoer-voice transitive by means of the comitative $-i$; $e \hat{a}-i$ (pronounced $\ddot{a} \ddot{a} i$ after sandhi rules have applied) means 'paddle something, transport something by paddling', in this case a

\footnotetext{
${ }^{16}$ An exception to the rule that a verb or adverb modifying an undergoer-voice verb is suffixed with $-i$ are the directional verbs $e e$ 'go up', woli 'go down', to 'go in' and lâ 'go out', which never take the suffix; cf. also footnote 14.

17 The line between verbs and manner adverbs in Äiwoo complex verb stems is not easy to draw. I classify a root as a verb if it is attested in an independent use as a predicate, whereas forms which are not attested with such a use but only as modifying another root in a complex verb stem are classified as adverbs. While this distinction is of course to some extent an artifact of the data available to me, it is common for verbs that occur in non-initial position of a serial verb construction to gradually become reduced in usage until they no longer occur outside the SVC context (Crowley 2002: 112-113); the boundary thus is not necessarily a sharp one, since the exact point where it is no longer possible (as opposed to just uncommon) to use a form as an independent predicate is difficult to identify.
} 
particular type of canoe. This form is in turn modified by the intransitive verb päko 'be good', which takes $-i$ as it modifies an undergoer-voice transitive:

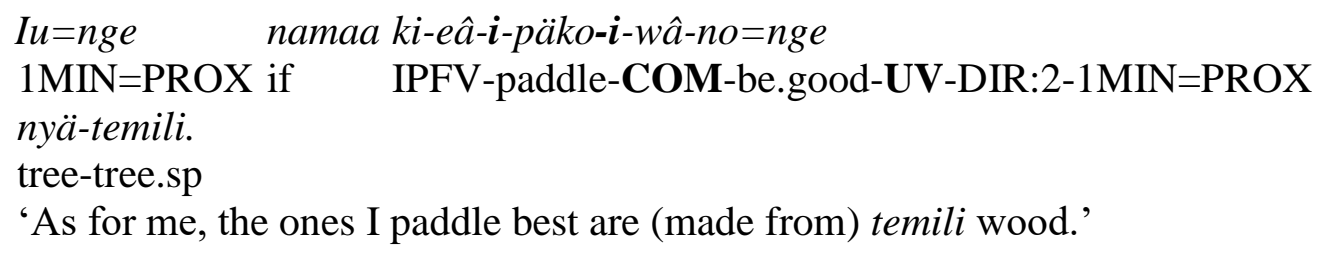

Some modifiers show $-n y i(i)$ rather than $-i$ when following an undergoer-voice stem. The choice is lexically determined, with $-i$ being by far the most frequent; -nyi(i) is attested with the following modifying verbs or adverbs: doo 'do like that', doo 'what', eke 'be quick', (lâ)oo 'always', mole 'exactly', ngege 'straight away', ngengäle 'back and forth', te 'groundlessly', waabo 'idly, effortlessly'.

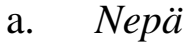
da-no
nä-ngäbe-eke-nyi-kä-mu.
betel.mix POSS:BETEL-1MIN IRR-pound-be.quick-UV-DIR:3-2MIN
'Pound my betel quickly.'
b. Doo i-vi-ngege-nyii-mu=wâ ngämi=nâ?
what PFV-plant.UV-straight-UV-2MIN=DIST OBL.PRO=DIST
'(When you first clear your garden,) what do you plant there straight away?'

4.6 The undergoer-voice cluster and $\mathrm{POc} *-\mathrm{i}$

In this section, I have presented a set of suffixes which show overlapping functions which all involve deriving undergoer-voice verb forms from various other structures. The forms of the suffixes are $-i$, -nyi(i), -ive, -(e) $\hat{a}$, and -nâa the functions I have discussed include causativization, deriving undergoer-voice forms from transitive actor-voice forms, deriving undergoer-voice transitives from intransitive roots, deriving undergoer-voice causatives from $w \hat{a}$-prefixed forms, and marking an intransitive modifier of an undergoer-voice stem.

While causatives are most frequently derived with the prefix $w \hat{a}-/ v \ddot{a}-$, sporadic examples exist of $-i$ and -ive forming causatives on their own. Undergoer-voice forms of transitive actor-voice verbs are formed by $-i$ and $-e \hat{a}$, while undergoer-voice transitives can be formed from intransitives by all the forms except the $n$-initial forms -nyi(i) and -nâ. Attaching to $w \hat{a}$-prefixed causatives seems to be possible for all the suffixes, although it is marginal for all except -eâ and $-n \hat{a}$; while intransitive modifiers to undergoer-voice stems take either $-i$ or $-n y i(i)$. Table 4 summarises these functions.

Table 4: Summary of functions of undergoer-voice forms

\begin{tabular}{|l|l|l|l|l|l|}
\hline & Causative & UV of $w \hat{a}$-causative & $\begin{array}{l}\text { UV from } \\
\text { transitive AV }\end{array}$ & $\begin{array}{l}\text { UV from } \\
\text { intransitive }\end{array}$ & $\begin{array}{l}\text { Modifier of UV } \\
\text { V1 in SVC }\end{array}$ \\
\hline$-i$ & $\mathrm{x}$ & $\mathrm{x}$ & $\mathrm{x}$ & $\mathrm{x}$ & $\mathrm{x}$ \\
\hline$-n y i(i)$ & & $\mathrm{x}$ & & & $\mathrm{x}$ \\
\hline$-i v e$ & $\mathrm{x}$ & $\mathrm{x}$ & $\mathrm{x}$ & $\mathrm{x}$ & \\
\hline$-e \hat{a}$ & & $\mathrm{x}$ & & $\mathrm{x}$ & \\
\hline$-n \hat{a}$ & & $\mathrm{x}$ & & \\
\hline
\end{tabular}


This complex of functions is closely parallel to that reconstructed for the Proto Oceanic suffix *-i (Pawley 1973, Evans 2003). ${ }^{*}-\mathrm{i}$ is reconstructed as a transitivizing suffix which had a causative function with Undergoer subject verbs, and an applicative function with Actor subject verbs. In the latter function it introduced $\mathrm{O}$ arguments with different semantic roles with different types of verbs: a location or goal role with motion and posture verbs; a location role with bodily process verbs; an addressee role with verbs of speaking; a stimulus role with verbs of speaking; and a patient role with some process-action verbs. In some Oceanic languages, reflexes of *-i occur in combination with causative prefixes (Evans 2003: 93-94). Moreover, *-i is thought to have attached to the final element of the verb complex rather than to individual verb stems (Evans 2003: 118).

With the qualification that the nature of the Äiwoo voice system means that the "applicative" function targets the voice-selected argument or "subject" rather than the "object" relation, this is essentially the same set of functions as I have described for -i/-nyi(i)/-ive/-eâl-nâ in this section. The use of -i/-nyi $(i)$ to mark an intransitive verb or adverb modifying an undergoer-voice root can be brought back to the verb complex-final position of POc *-i. However, this function seems to have been reinterpreted as a form of agreement in voice between the modifier and the root, and disconnected from the use of $-i$ to indicate transitivity or undergoer voice of the verb complex as a whole, as can be seen from the fact that $-i$ can occur multiple times with multiple modifiers (examples 34-35) and cooccurs with $-i$ used to form a comitative transitive undergoervoice stem from an intransitive root (example 36). This is reminiscent of the situation in the Papuan Tip language Saliba, where the suffix $-i$ marks agreement in transitivity between a modifying verb and an initial transitive stem (Margetts 199: 106).

If the functions of the set of Äiwoo suffixes described here derive from the distribution of POc *$i$, we must ask how the formal variation in Äiwoo has arisen. I take $-i$ to be an uncontroversial reflex of *-i. Where the variant form -nyi(i) may have come from is unclear, but note that a few Oceanic languages show a transitive - ni the origins of which are not clear (Evans 2003: 150-156, 189-90).

I propose that $-(e) \hat{a}$ may be a reflex of the reconstructed POc $3 \mathrm{SG}$ object enclitic *=a. POc $*_{-i}$ is reconstructed as having occurred only with consonant-final and *a-final verb stems, while other verbs took the object enclitics directly (Evans 1995, 2003: 104-109). Reflexes of $*_{-i}$ and $*=a$ show divergent functions in some Southeast Solomonic languages, in the sense that some verbs can be transitivized either by the *-i reflex which in turn is followed by the object marker, or by the object marker directly, with a difference in the semantic role of the $\mathrm{O}$ argument:

Longgu (Hill 1996 cited in Evans 2003: 98):

$\begin{array}{llll}\text { a. luda-ngi-a niu } & \text { b. } & \begin{array}{l}\text { luda-a } a \\ \text { load-3SG iolai } \\ \text { load-TR-3SG coconut } \\ \text { 'load the coconuts' }\end{array} & \begin{array}{l}\text { 'load the canoe' } \\ \text { loanoe }\end{array}\end{array}$

In Äiwoo, the differentiation aligns with distribution rather than with semantic role, in the sense that $-e \hat{a}$ is productively used only in $w \hat{a}$-causatives, where $-i$ is only marginally attested, whereas $-e \hat{a}$ in turn derives noncausative UV forms only of a small set of verbs.

The origins of -nâ are more difficult to account for. Given that both $-i$ and $-(e) \hat{a}$ have an n-initial alternant, which in both cases appear to be lexically determined, one might ask whether it is the same set of verbs that require the $\mathrm{n}$-form in both instances. Unfortunately, this cannot be determined from the available data, since the roots appearing as modifiers in a complex verb 
stem show little overlap with those appearing in causative constructions in my material. The one root that I have attested in both environments does suggest that this might be the case; waabo 'be idle, be tame' takes -nyi when modifying an undergoer-voice verb in a complex verb stem, and $n \hat{a}$ when causativized:

a. Lamaa dowâlili ki-gosi-waabo-nyi-epu-i-i
if child IPFV-carry.on.head.UV-be.idle-UV-also-UV-3AUG
$n g \hat{a} \hat{a} g u$.
bush
'Maybe the children can also carry it easily back from the gardens.'
Vili no-u $\quad k u$-wâ-wabo-nâ.
parrot POSS:GEN-1MIN IPFV-CAUS-be.idle-UV
'I tame my parrot.'

Perhaps this is suggestive of an origin in a thematic consonant, as occurs with reflexes of both $*_{-i}$ and *akin[i] in a number of Oceanic languages; the most generally accepted analysis is that such consonants derive from original stem-final consonants that have since been lost in all environments except preceding the suffix ${ }^{18}$. This does not explain, however, why the $n$-form would appear with a loanword like tepeu 'be stupid', from the Polynesian Outlier VaeakauTaumako.

The real mystery form is the suffix -ive. The participant roles that it introduces overlap considerably with those reconstructed for $*-i$, in particular patient/theme and stimulus arguments. Given the classification of Äiwoo as showing a Philippine-type symmetrical voice system, argued for in 3.4 above, it is moreover interesting to note some parallels between -ive and voice markers in present-day Philippine languages. As discussed in 4.3, while it is similar to an applicative in that it introduces an $\mathrm{O}$ argument into the clause core, -ive differs from a canonical applicative in that the argument it introduces becomes the voice-selected argument - that is, the "subject" rather than the "object". This function is also found with nonactor voice markers in Philippine languages. In Tagalog, the patient-voice suffix -in and the locative-voice suffix -an can apply to monovalent roots, adding a patient or location argument which has voice-selected status (Kaufman 2009, p.c.). However, unlike in Tagalog, where PV -in and LV -an enter into the regular paradigm of voice markers, forms in -ive do not appear to alternate with actor-voice forms of transitive verbs; that is, -ive specifically functions to add an argument to intransitive verbs, and in this it shows parallels to applicatives.

The causative function found with a few roots for Äiwoo -ive is similarly found for nonactor voice markers with a small number of stative roots in Tagalog, e.g. init 'hot' - init-in (patient voice) 'heat (make hot)', bilis 'fast' - bilis-an (locative voice) 'speed up (make fast)' (Dan Kaufman p.c.). The function of forming undergoer-voice causatives in combination with a causative prefix, also marginally attested with -ive, is also found with the Tagalog patient-voice suffix -in, which may occur in combination with causative $p a-$. In cases where a form with -in or -an can give a causative reading for the same root without $p a-$, the difference is generally one of more vs less direct causation, e.g. itim 'black', itim-an 'blacken', pa-itim-in 'make black' (Dan Kaufman p.c.).

\footnotetext{
${ }^{18}$ See Arms (1973), Lichtenberk (2001), Ashley (2012) for discussions of possible semantic conditioning on thematic consonants in various Oceanic languages.
} 
Thus the functions of -ive show clear parallels to functions found with the patient-voice and locative-voice suffixes in Tagalog. This is interesting in the present context because it is the PMP patient-voice and locative-voice forms which are thought to have merged into POc $*_{-i}$. However, I have argued above that Äiwoo has another reflex of $*$-i, namely $-i$, which overlaps with -ive in distribution, including appearing on some of the same verb roots, as seen in examples (24-25); and I have no explanation for the form -ive.

To conclude this section, I have argued that the cluster of undergoer-voice suffixes found in Äiwoo largely continue the functions and distribution of the POc suffix *-i; and that, where a plausible origin can be identified, they reflect $*$-i and the 3 SG object clitic $*=a$, which attached directly to those verbs which for phonological reasons did not take *-i. However, a number of unanswered questions remain regarding the formal differentiation that has taken place in Äiwoo.

\section{The circumstantial voice clitic $=\mathrm{C} \ddot{a}$}

5.1 Distribution and functions

In addition to the complex of suffixes discussed in section 4, another way of adding an argument to an $\ddot{A} i w o o$ clause is with the clitic $=\mathrm{C} \ddot{a}$. I analyze this clitic as a circumstantial voice marker which promotes a peripheral participant to the status of voice-selected argument. As noted in 3.2.3, core arguments in Äiwoo are unmarked, whereas obliques and adjuncts are marked by a preposition; the most common prepositions are ng $\ddot{a}$ 'general locative' and go 'for, with, because of'. When the clitic $=\mathrm{C} \ddot{a}$ is added to the verb, a peripheral participant is promoted to voiceselected status and appears, typically, in preverbal position, and without a preposition. As illustrated in (16) and (40), the $=\mathrm{C} \ddot{a}$-marked form takes actor suffixes, regardless of the status of the root as intransitive, actor voice or undergoer voice; in other words, =C $\ddot{a}$-marked forms pattern syntactically and morphologically like transitive non-actor-voice forms, and promote a peripheral participant to voice-selected status. Accordingly, I analyze it as a circumstantial voice marker.
$\begin{array}{lll}\text { a. } \quad \text { I-ku-mâa } & \text { go } & \text { pepa. } \\ \text { 1MIN-IPFV-smoke } & \text { with } & \text { paper }\end{array}$
'I smoke with (rolling) paper [as opposed to with a pipe].'

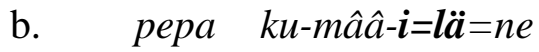
paper IPFV-smoke-3AUG $=\mathbf{C V}=\mathrm{PROX}$
'paper to smoke with'
a. I-lile ngä ny-ângâ.
PFV-marry LOC place-DEM:DIST
'She is married in that place [i.e. married to a local and living there].'
b. Temotu=ke ki-lile-du=nä.
island=PROX IPFV-marry-all=CV
'He married in all the islands here.'

The initial consonant of the clitic is determined largely by the person/number properties of the immediately preceding host morpheme, though some lexical roots and grammatical markers also condition specific forms. The default form is $=k \ddot{a}$, which appears in nearly all cases where the host does not show person/number marking. =ngä is found following $1 \mathrm{MIN}$ and $1 \mathrm{st}+2 \mathrm{nd}$ person forms; =w $\ddot{a}$ following $1 \mathrm{AUG}$ and 2nd person forms, as well as the aspect clitics =jo and =to; =n $\ddot{a}$ 
following 3MIN forms, the unit-augmented suffix $-l e$, and the negation clitic $=g u$; and $=l \ddot{a}$ following $3 \mathrm{AUG}$ forms. In spite of this interaction with the preceding element, I analyse $=\mathrm{C} \ddot{a}$ as a clitic, because it attaches to the verb phrase including, in the undergoer voice, a postverbal A NP (see example 50 below); that is, it selects a phrase rather than a lexical item as its host (Næss 2015b).

Note that $=\mathrm{C} \ddot{a}$ contrasts with $n g \ddot{a} m i$, which is a pro-form for a prepositional phrase with the spatial preposition $n g \ddot{a}$. Unlike $=\mathrm{C} \ddot{a}, n g \ddot{a} m i$ does not influence the argument structure of the verb. In (42a), the intransitive verb ko 'lie' retains prefixed person marking when ngämi is used to refer back to the preceding prepositional phrase ngâ nuwopa enge; in other words, the construction remains intransitive. By contrast, (42b) shows $=$ C $\ddot{a}$ with the same verb and suffixed person marking.
$\begin{array}{lll}\text { Iumu } & \text { mo } & \text { gisi-mu } \\ \text { 2MIN } & \text { CONJ } & \text { brother-2M }\end{array}$
mi-nä-e-ko-kä-le ngämi.
po-le $=$ to
$\begin{array}{ll}\text { ngâ } & \text { nuwopa } \\ \text { LOC } & \text { house }\end{array}$
enge,
2MIN-IRR-PA-lie-UA OBL.PRO
'You and your brother go to this house and lie in it.'
$\begin{array}{lll}\text { b. } \quad \text { ila } & \text { danyige } & k i-o-k o-\text { ngopu=wä }=n e \\ \text { DIST mat } & \text { IPFV-PA-lie-1AUG }=\mathbf{C V}=\mathrm{PROX}\end{array}$
'the mats that we lie on'

(42b) also shows that $=\mathrm{C} \ddot{a}$ is required when a peripheral argument is relativized on. This is parallel to relativization of core arguments where relativization of A requires the actor voice while relativization of $\mathrm{O}$ requires the undergoer voice (with some exceptions, see Næss 2015: 289-291). This is further evidence that $=\mathrm{C} \ddot{a}$ forms part of the voice system.

Although the circumstantial-voice function is primary, $=$ C $\ddot{a}$ shows a number of minor functions which it does not seem feasible to analyze as voice marking, though they may be related to the voice function to varying extents. In this section, I will give a detailed description of the functions of $=\mathrm{C} \ddot{a}$; and in 5.2 below I will compare them to those that have been reconstructed for POc *akin[i].

In its basic function as a circumstantial voice marker, $=\mathrm{C} \ddot{a}$ promotes peripheral participants with a range of semantic roles. Locative (43a) and temporal (43b) arguments are common across a range of semantic verb types such as position verbs, motion verbs and activity verbs; with the latter type, instruments (43c) are also frequently found:
a. Numobâ
$k i-v e e-i=$ to
hole IPFV-scoop.UV-3AUG=now
go nâ-ko ilâ sime mi-nubo
ngä belekraon $=k \hat{a}$
CONJ IRR-lie DIST person one-die
LOC cemetery=DIST
'They dig a hole in the cemetery for the dead person to lie in.'
b. Nyidâbu ilâ wo-ule-ngopu=wä ki-leluwo-ngopu=wä $=n \hat{a}$. day DIST go-across-1AUG=CVIPFV-dance-1AUG=CV=DIST 'The day that we went across to dance.'

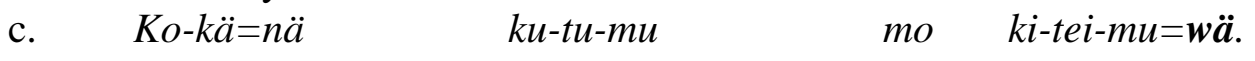 say-DIR:3=CV IPFV-bring-2MIN and IPFV-fish-2MIN=CV
'She said, 'Take it [a fishing net] and fish with it."'


For what Dixon (1994) calls extended intransitive verbs, which occur with an oblique O argument, this oblique can be promoted to VSA status by means of $=\mathrm{C} \ddot{a}$; this is illustrated below with the verbs vevaale 'look after, watch over, tend' (44) and vaavi 'dress in, wear' (45):
$K \hat{a}-n o=n g \ddot{a}$ say- $1 \mathrm{MIN}=\mathrm{CV}$
nyä-vaavi
go nupwää mi-mou.
'I want to wear the blue shirt.'
b. de-nâ-vaavi-de=ngä.
thing-IRR.dress-1+2AUG=CV
'clothes (lit. things we wear)'

ki-vevaale

go mi-ki-li-bei

friend.1MIN=DIST IPFV-look.after

PREP one-IPFV-3AUG-be.ill

ngâ nuwopa eä nyi-bei.

LOC house of.3MIN NMLZ-be.ill

'My friend looks after the sick people at the clinic.'
b. Ki-vevaale-ngopu=w $\ddot{a} \quad$ ilâ paveli e $\ddot{a} \quad$ nulie $=k \hat{a}$.
IPFV-look.after-1AUG=CV DIST garden of.3MIN pana=DIST
'We tend that pana [lesser yam, Dioscorea esculenta] garden.'

With speech verbs, $=\mathrm{C} \ddot{a}$ introduces the content of speech as the VSA. $=\mathrm{C} \ddot{a}$ is obligatory with the speech verbs $k o$ 'say' and $k \ddot{a}$ 'think, want, say', which like English say is used to either directly or indirectly quote the actor's speech:
a. Mo $k o-k \ddot{a}-i-l e=n \ddot{a}$,
Päko, ki-vaave-wâ-ngo-le.
CONJ say-DIR:3-3AUG-UA=CV good IPFV-show-DIR:2-1AUG-UA
'And they said, Okay, we will show you.'
b. Kä=nä "Kälää=to ijii-le=nâ?"
say $=\mathbf{C V} \quad$ where $=$ now 3 AUG-UA=DIST
'She said, "Where are they?",

The intransitive speech verb lopâ 'talk, speak' can be transitivized in two ways. With -ive it means 'tell (a story)', while with $=\mathrm{C} \ddot{a}$ it means 'talk about (a topic)':
a. Kâa-no=ngä
nâ-lopâ-ive-wâ-no=nge
say- $1 \mathrm{MIN}=\mathrm{CV}$
IRR-talk-UV-DIR.2-1MIN=PROX
naae wä
tepekâ mo vili.
story of.3MIN flying.fox CONJ parrot
'I want to tell you the story about the flying fox and the parrot.'
b. Ile ngä bäli le kâ-mu=wä
PROX LOC side PROX say-2MIN=CV
$n \hat{a}-l o p \hat{a}-l \hat{a}-k \hat{a}-m u=\boldsymbol{w} \ddot{\boldsymbol{a}} \ldots$
IRR-talk-go.out-DIR:3-2MIN=CV

\footnotetext{
19 Äiwoo does not make a lexical distinction between green and blue, but does distinguish 'light green/blue' (momalâ) from 'dark green/blue' (mou).
} 
'Concerning the topic that you want to talk about now ...'

Arguably, the story may be seen as more patient- or theme-like in that it is the product or outcome of the telling, and so closer to the types of role typically introduced by -ive, whereas $=C \ddot{a}$ again denotes the content of the speech act.

In a couple of cases, $=$ C $\ddot{a}$ may be understood as having a causative function. As Evans (2003: 182) notes, causatives of motion verbs share with comitatives the fact that the agent makes the object move; the difference is whether the agent moves along with it or not. Similarly, drawing a precise line between a stimulus and a cause is not straightforward. The intransitive verb giâa 'be happy' can take an oblique phrase referring to the stimulus or source of the happiness, structurally parallel to the extended intransitive verbs illustrated in (44-45). When the oblique stimulus is promoted to VSA by means of $=\mathrm{C} \ddot{a}$, this gives a causative-like reading, since the stimulus is essentially the cause of the being happy; so in (48b), the gift of the shark makes the spirit happy:
a. I-giââ-mana-wâ ngâgu-mu.
1MIN-be.happy-very-DIR:2 to-2MIN
'I am very happy with you.'
b. Mi-vili=nä=nâ na-uusi lâ nää
$\mathrm{BN}$-five $=\mathrm{CV}=\mathrm{DIST}$ POSS:FOOD.3MIN-again DIST spirit nogo=nâ,
POSS:TOOL.3MIN=DIST
nä-giâa $\quad n \ddot{a} \ddot{a} \quad n o g o=n \ddot{\boldsymbol{a}}=n \hat{a}$.
IRR-be.happy spirit POSS:TOOL=CV=DIST
'(after the fisherman has caught four sharks,) the fifth again is for his [protective] spirit, to please his spirit with.'

giâa can also occur in the productive causative construction with wâ-, as in (49); the gift in (48b) is clearly a stimulus, whereas the introduced cause in (49) is an agent:
I-wâa - giâa $-\boldsymbol{e} \hat{\boldsymbol{a}}-m u$
iu.
PFV-CAUS-be.happy-UV-2MIN
1MIN

'You have made me happy.'

In general, inanimate causes tend to be encoded by $=\mathrm{C} \ddot{a}$ rather that causative $w \hat{a}-$, as illustrated in (50) (compare wâ-nubo CAUS-die 'kill' in example 17 above):
Ku-lu-pwâleto
go de-kää-i
IPFV-3AUG-put.in
$k \ddot{a}-i=l \ddot{a}$
PREP thing-know-3AUG
say-3AUG=CV
namaa ku-nubo
sime $=k \ddot{a}$.
MOD IPFV-die person=CV
'They would put in things [magical remedies] that they knew people would die from.'

In examples (51ab), with the verb tube 'be blocked, be closed', there is a clear difference in argument structure between the $w \hat{a}$-marked causative $w \hat{a}$-tube- $\hat{a}$, where the VSA is the object 
blocked and there is an agent causer, and the $=\mathrm{C} \ddot{a}$-marked form where the VSA is the thing or substance something is blocked with:
a. Lâ $\quad k u-\boldsymbol{w} \hat{\boldsymbol{a}}-\mathrm{tube}-\hat{\boldsymbol{a}}-m u=t o=w \hat{a}$
DIST IPFV-CAUS-be.blocked-UV-2MIN=now=DIST
lâto $m i$-ki-vei-ee $=$ to $=w \hat{a}$.
thus 2MIN-IPFV-weave.AV-go.up=now=DIST
'Then you close [the basket] and weave upwards.'
b. Ile ku-tube-wâanä=ne, de-enge doo=le?
this IPFV-be.blocked-DIR:2=CV=PROX thing-DEM:PROX what=PROX 'This thing blocking [the door], what is it?

Again, (51b) could be interpreted as having causative semantics in the sense that the instrument is causing the door to be blocked.

I have two instances - both from the same sentence - of a motion verb where $=\mathrm{C} \ddot{a}$ appears to have a clearly causative function. Wo 'go' is a regular intransitive verb taking actor prefixes:

$$
\begin{aligned}
& M e-k u-w o-d u=t o=w \hat{a} . \\
& \text { 1AUG-IPFV-go-all=now=DIST } \\
& \text { 'We all go.' }
\end{aligned}
$$

In (53), however, wo-oli 'go down' takes $=\mathrm{C} \ddot{a}$ and actor suffixes, and the reading is 'cause to go down/put down':

$$
\begin{array}{lll}
\text { Lâ } & \text { tent } & \text { ku-wo-oli-mä-ngopu }=\boldsymbol{w a} \ddot{\boldsymbol{a}}=n \hat{a} \\
\mathrm{DIST} & \text { tent IPFV-go-go.down-DIR: } 1-\mathbf{A} \mathbf{A G}=\mathbf{C V}=\mathrm{DIST} \\
o & \text { tarpaulin la ku-wo-oli-mä-ngopu=wä }=n \hat{a} .
\end{array}
$$

CONJ tarpaulin DIST IPFV-go-go.down-DIR:1-1AUG=CV=DIST

'We put the tents down, we put the tarpaulins down.'

This is the only example in my data where $=\mathrm{C} \ddot{a}$ is used with an animate causer.

Finally, a comitative function with motion verbs seems to be possible, though rare:

$$
\begin{aligned}
& \text { I-wo-to- } m \ddot{a}=k a a=k \ddot{a} \quad \text { lâ first catch. } \\
& \text { PFV-go-go.in=FUT }=\mathbf{C V} \text { DIST first catch }
\end{aligned}
$$

To summarize, the main function of $=\mathrm{C} \ddot{a}$ is to promote a variety of circumstantial participants to voice-selected status. These participants show a range of semantic roles such as instrument, locative, temporal, and manner. With so-called extended intransitive verbs, which take a prepositional complement, $=\mathrm{C} \ddot{a}$ promotes this complement to voice-selected argument. Another core function of $=\mathrm{C} \ddot{a}$ is to introduce the content of speech for speech verbs; it is obligatory with the verb kä 'say, think' and ko 'say' when these are followed by a direct or indirect quote. Moreover, $=\mathrm{C} \ddot{a}$ can have a causative function with some verbs, and a comitative function with motion verbs, though the latter is very rare in my material. 


\section{$5.2=\mathrm{C} \ddot{a}$ and $*$ akin[i]}

In 4.6 above, I argued that the distribution and functions of the Äiwoo undergoer-voice suffixes closely parallel those reconstructed for POc *-i. In this section, I will show that the same is the case for $=\mathrm{C} \ddot{a}$ and the other transitivising morpheme reconstructed for POc, namely $*$ akin[i] . The hypothesis that $=$ Cä reflects *akin[i] was put forth in Næss (2015a), though on a fairly general basis; the detailed description presented in 5.1 allows us to assess this hypothesis more carefully.

Table 5, from Evans (2003: 235), lists the roles reconstructed for POc *-i vs *akin[i]:

Table 5: Types of roles denoted by POc *-i and *akin[i] (Evans 2003: 235)

\begin{tabular}{|l|l|l|}
\hline Verb type & $\begin{array}{l}\text { roles denoted by } \mathbf{O} \text { with } *-\mathbf{i} \\
\text { and/or object enclitics }\end{array}$ & roles denoted by *akin[i] \\
\hline motion verbs & location/goal & concomitant \\
\hline $\begin{array}{l}\text { psychological and } \\
\text { emotional states }\end{array}$ & stimulus & cause/stimulus \\
\hline speech and cognition & addressee & content \\
\hline excretion/secretion & location & product \\
\hline process-action verbs & patient & instrument, beneficiary \\
\hline
\end{tabular}

Along with a number of other peripheral roles, instruments are promoted by $=\mathrm{C} \ddot{a}$, as reconstructed for *akin[i] with process-action verbs. Note the reconstruction of *akin[i] as having indicated the stimulus of verbs of psychological and emotional states; as shown in (4849), such stimulus arguments tend to be encoded by $=\mathrm{C} \ddot{a}$, whereas causing agents are encoded by $w \hat{a}-$. Note also that there is a certain overlap between $-i v e$ and $=\mathrm{C} \ddot{a}$ in this domain, consistent with the fact that a stimulus role for verbs of psychological and emotional states is reconstructed for both $*_{-i}$ and $*_{\text {akin }}$ i] ; compare $(48 \mathrm{~b})$ to $(55)$ :

$$
\begin{aligned}
& \text { Ilâ nyidâbu eââ maa doo, } \\
& \text { DIST day DEM:DIST MOD like.this } \\
& \text { ku-lu-pwate mo ki-li-pängä, } \\
& \text { IPFV-3AUG-dance CONJ IPFV-3AUG-eat.AV } \\
& \text { lâ } \quad k i \text {-giâa } \hat{a}-\boldsymbol{i v e}-i=t o=w \hat{a} \quad \text { lâ nyi-wo-ute-mä-na } \\
& \text { DIST IPFV-be.happy-UV-3AUG=now=DIST DIST NMLZ-go-back-DIR:1-NMLZ } \\
& \text { nogo-i=lâ peliva-no mi-li-sigiläi ê̂â. } \\
& \text { POSS:TOOL-3AUG=DIST PL-child one-3AUG-man DEM:DIST } \\
& \text { 'All that day it was like this, they danced and ate, they celebrated those boys coming }
\end{aligned}
$$

While the $=\mathrm{C} \ddot{a}$ construction in (48) casts the shark as a kind of instrument that the fisherman uses to please the spirit, giâa-ive seem to have the more specific and perhaps lexicalized meaning 'celebrate'.

The obligatory appearance of $=\mathrm{C} \ddot{a}$ with speech verbs does not obviously follow from the analysis of $=\mathrm{C} \ddot{a}$ as a circumstantial voice marker. However, indicating the content of speech and cognition verbs is one of the functions reconstructed for *akin[i], and so if $=\mathrm{C} \ddot{a}$ is a reflex of *akin[i], this explains why it shows this function. 
A causative function of $=\mathrm{C} \ddot{a}$ is attested, but rare, which is more or less as expected for a reflex of *akin[i]; some Oceanic languages show this function with only one verb, and even where there are more, Evans (2003: 200) notes that "it never seems to be very many verbs which take *akin[i] reflexes with the causative use". A comitative function with motion verbs is possible for $=\mathrm{C} \ddot{a}$, though extremely rare in my data; as described in 4.3 , this function is mostly filled by $-i$. It is worth noting, however, that the verb wo 'go', which was shown as taking comitative $=\mathrm{C} \ddot{a}$ in (54), is not attested with comitative $-i$; we may thus hypothesize that the use of $-i$ vs $=\mathrm{C} \ddot{a}$ in a comitative function is determined by the verb.

The functions of $=\mathrm{C} \ddot{a}$ thus to a considerable extent match those reconstructed for POc *akin[i]. The main differences are, firstly, that the comitative function reconstructed for *akin[i] has largely been taken over by $-i$, and to some extent -ive; and that the range of roles found in particular with motion and process-action verbs has expanded beyond those reconstructed for *akin[i], as =C $\ddot{a}$ is associated with the promotion of oblique participants in general. Despite this expansion, however, the patterns originally associated with *akin[i] seem largely to be present in the Äiwoo data.

It thus seems reasonable to hypothesize that $=\mathrm{C} \ddot{a}$ may be a reflex of $*$ akin[i], but two things are required to substantiate this hypothesis: firstly, evidence that the hypothesis is plausible from a phonological perspective, and secondly, an account of how *akin[i], which is reconstructed as a suffix and a preposition, would have developed into a voice-marking clitic. Below I will address each of these points in turn.

Although current understanding of the historical phonology of Äiwoo is rather sketchy, for $=\mathrm{C} \ddot{a}$ to originate in *akin[i] is plausible based on what we do know. POc */k/ becomes zero between vowels in Äiwoo (Ross and Næss 2007: 463). Nouns in Äiwoo regularly lose the final syllable of their POc source (Ross and Næss 2007: 465). At least one form suggests that final *n is lost in words other than nouns: POc *payan 'eat' > Äiwoo väng ä 'eat.AV'. The loss of *k and *n[i] would leave *ai; for this form to assimilate to $\ddot{a} / \mathfrak{a} /$ is entirely expected, cf. e.g. the directional suffix $-m \ddot{a}$ 'to/for $1^{\text {st }}$ person', from POc *mai.

An unresolved question is the origin of the initial consonant of the clitic. As noted in 4.6, a number of Oceanic languages show so-called thematic consonants with reflexes of both $*_{-i}$ and *akin[i], where an original stem-final consonant has been retained only in combination with the suffix. However, such an analysis presupposes that *akin[i] originated as a suffix added to verb stems. Evans (2003: 205-209) reconstructs POc *akin[i] both as a suffix and a preposition. Given its present-day distribution as a VP-final enclitic, the source of Äiwoo $=\mathrm{C} \ddot{a}$ would seem to have been a preposition; and it is unlikely that an original preposition would have acquired a thematic consonant from the end of verb stems.

Nor do the consonant alternations found with $=\mathrm{C} \ddot{a}$ appear to be consistent with an origin in stemfinal consonants. As noted above, the alternation is largely conditioned by person-number properties of the host, and where examples can be found of $=\mathrm{C} \ddot{a}$ attaching directly to a verb root for which a consonant-final POc form has been reconstructed, the consonant does not generally match this original stem-final consonant. For example, Äiwoo engi 'cry' reflects POc *tanis, and many present-day Oceanic languages show /s/ or another reflex of *s as a thematic consonant when their reflex of *akin[i] appears with this verb (Evans 2003: 207-208). However, while the details of sound correspondences between POc and Äiwoo remain to be worked out, the $n$ appearing in (56) is an unlikely reflex of $*_{s}$ : 


$$
\begin{aligned}
& \text { de-ki-engi=nä }=n e \\
& \text { thing-IPFV-cry }=\mathrm{CV}=\mathrm{PROX} \\
& \text { 'what he is crying for' }
\end{aligned}
$$

It must be noted that many Oceanic languages show cases of thematic consonants that are not consistent with an original stem-final consonant (Evans 2003: 211-229); but the particular pattern of consonant alternations found in Äiwoo, as well as its likely origin in a preposition, is not easily compatible with a thematic-consonant account.

It is likely, however, that an answer to this question will have to be sought within a broader context than simply the distribution of *akin[i], because the consonant alternation found with $=\mathrm{C} \ddot{a}$ is also present with two other sets of clitics, namely the future/habitual clitic $=\mathrm{C} a a(57)$ and the deictic clitics $=\mathrm{C} e$ 'proximal' and $=\mathrm{C} \hat{a}$ 'distal' (58). These follow the same pattern of alternation conditioned by the person/number properties of the host as does $=\mathrm{C} \ddot{a}$.
a. Ilâ ki-âpoto $=\boldsymbol{k a a}=k \hat{a} \quad$ dee dä tuge. DIST IPFV-enter=FUT=DIST FOC some time 'He will enter at another time.'
b. I-luwa-kâ-ngopu=waa ngâ nuwopa ki-to=nä. PFV-take-DIR:3-1AUG=FUT LOC house IPFV-exist $=\mathrm{CV}$ 'We take it from the house where it is kept.'
c. Ki-te-usi-kâ-no=ngaa. IPFV-see-again-DIR:3-1MIN=FUT
'I will see her again.'
d. $\quad K i$-väsili-i=laa $=k \hat{a}$
ki-kaluâ.
IPFV-prepare.UV-3AUG=FUT=DIST IPFV-fermented.breadfruit 'They will make it into kaluâ (fermented breadfruit).'
a. Lâto $k u-n u w a d e=k \hat{a}$... thus IPFV-be.heated=DIST 'Then when it's hot ...'
b. Ilâ nâbo=kâ
DIST dried.breadfruit $=$ DIST lâ i-eangi-ngopu=wâ. 'Then we start slicing the nâbo (dried breadfruit chips).'
c. Maa ilâ wâi $k \hat{a}-n o=n g \ddot{a} \quad d e$-nâ-lopâ-ive-wâ-no=ngâ. if DIST just say-1MIN=CV thing-IRR-talk-UV-DIR:2-1MIN=DIST 'That's all I wanted to say.'
d. Ku-wâbâ-to-kä-i=lâ ngâ nubuleke-i. IPFV-show-go.in-DIR:3-3AUG=DIST LOC knee-3AUG 'They measure it to the knee.'

Given that the alternation is conditioned primarily by person and number, it is tempting to assume a historical link to person marking. A few hints in this direction may be found; for example, the Santa Cruz languages Natügu and Nalögo both have $n g$-initial 1MIN pronoun forms (van den Berg and Boerger 2011: 230, Alfarano 2019), and POc shows an *r in 3PL which might be the source of the Äiwoo $l$ forms (Lynch, Ross and Crowley 2002: 67). However, a 
much better understanding both of the possible sources and the historical processes involved would be required to substantiate this hypothesis.

With the reservation that the consonant alternation remains unaccounted for, then, the hypothesis that $=$ C $\ddot{a}$ reflects $*$ akin $[i]$ may be considered to be plausible from a phonological perspective. The second question is how an original preposition might have developed into an enclitic marking a voice function, in itself an unusual situation. A clue may be found in Alfarano's (2019) discussion of applicative-like forms in Nalögo, a language of Santa Cruz and one of Äiwoo's closest relatives. Alfarano shows that the Nalögo form -neba is in some contexts ambiguous between an applicative and an oblique pro-form picking up the reference of a fronted or topicalized oblique participant. (59) shows the function of -neba as an applicative. In (59a) the intransitive verb $l \hat{a}$ 'talk' is followed by a prepositionally marked adjunct representing the addressee; in b, however, the verb is applicativized and the addressee argument obwe 'child' appears as a direct argument of the verb. Note the $3 \mathrm{MIN}$ clitic $=l e$ on the verb in (59b); this person marker appears only on transitive predicates.

Nalögo (Alfarano 2019)
a. $\quad$ Kopyo leplë jâ tü-lâ=bwe
exist person PROG RL.N3AUG -talk=PDIR.thither
ba mete=de.
PREP friend=3MIN.POSS
'There is someone talking to his friend.'
Kopyo leplë tü-lâ-neba=le
exist person RL.N3AUG-talk-APPL=3MIN
obwe ne=de.
child POSS.GEN=3MIN.POSS
'There is someone talking to his child.'

In (60), the recipient argument is fronted, and Alfarano argues that -neba could here be interpreted either as an applicative, or as a pro-form for a fronted oblique argument; in the closely related language Natügu, according to Alfarano, -neba only has the latter function.

$$
\begin{aligned}
& \text { Nalögo (Alfarano 2019) } \\
& \text { Nünge kâ i-ka-neba=le } \\
& \text { boy DET N3AUG.PFV-give-APPL/OBL=3MIN } \\
& \text { töbao kâ i-kele. } \\
& \text { papaya DET N3AUG.PFV-be.good } \\
& \text { 'The boy she gave the papaya to is good.' }
\end{aligned}
$$

Alfarano's argument is that the original oblique pro-form was reanalyzed as an applicative, with constructions such as (60) as the bridging context. While -neba is clearly not cognate with $\ddot{A}$ iwoo $=\mathrm{C} \ddot{a}$, a similar duality of function might account for the development of the reflex of *akin[i] into present-day $=\mathrm{C} \ddot{a}$. Synchronically, there is little doubt that $=\mathrm{C} \ddot{a}$ functions as a voice marker; this is shown by the fact that when the clitic is added to an actor-voice stem, person marking changes from prefixing to suffixing. Nevertheless, there are a few cases where $=\mathrm{C} \ddot{a}$ seems to be associated with a topicalized argument, without having any clear valency-increasing function, as in (61): 
Ile nyenaaee ile la-ki-mu=wä ...

PROX tree DEM:PROX PROX chop-break-2MIN=CV

'These trees that you chopped down ...'

The complex verb stem laki 'chop (a hard brittle object)' is a transitive undergoer-voice form taking the object chopped as its VSA; it is not clear, therefore, what the clitic $=\mathrm{C} \ddot{a}$ is contributing in this example.

From a diachronic perspective, the kind of structure illustrated by Alfarano for Nalögo, where a fronted oblique participant is resumed by a pro-form following the verb - essentially a stranded preposition - would be well placed to be reanalyzed as a circumstantial voice marker within Äiwoo's symmetrical voice system. Note that unlike the Santa Cruz languages Nalögo and Natügu, which are verb-initial, the unmarked word order in Äiwoo is for the voice-selected argument to be clause-initial; that is, the actor of the actor voice and the undergoer of the undergoer voice. In other words, the clause-initial position is associated with the status of voiceselected argument (Næss 2015a, b), and thus a morphological marker appearing when an oblique argument is placed in preverbal position would be easily reanalyzable as marking the promotion of that oblique argument to VSA status.

A "trace" function of *akin[i] reflexes, i.e. functioning as a pro-form for a fronted oblique argument, is attested in some Oceanic languages. Evans (2003: 204) suggests that this may be an innovation in Fijian and Polynesian languages, since the only examples attested at the time stem from these languages; however, it is also found in the Admiralties language Paluai (Schokkin 2020: 256). Assuming that $\ddot{A} i w o o=\mathrm{C} \ddot{a}$ is indeed a reflex of *akin[i], this suggests that the trace function of *akin[i] should be reconstructed back to POc, or at the very least, that *akin[i] could be stranded when its complement was fronted, leaving it susceptible to a reanalysis as a trace element.

\section{Oceanic morphology in a Philippine-type system?}

In section 3.3 of this paper, I described Äiwoo as having a Philippine-type symmetrical voice system, albeit one that is much reduced compared to the usual 4-5 voices of Philippine languages. In sections 4-5, I suggested that much of the morphology involved in voice and valency marking in Äiwoo has plausible origins in forms reconstructed for Proto Oceanic. This puts Äiwoo in the interesting position of being a Philippine-type language with Oceanic morphology. Given the standard account of the Proto Oceanic verbal system as arising out of a reduction and reanalysis of the PMP system in which the original voice system was reanalyzed as marking distinctions in transitivity, this raises the question of how such a situation may have come about.

The PMP voice-marking system is reconstructed as in Table 6 (adapted from Ross 2002: 49) ${ }^{20}$, illustrated with the root *kaRat 'bite':

\footnotetext{
${ }^{20}$ Ross' reconstruction includes a second row of 'Projective' forms in the 'Non-indicative' set, while the forms reproduced here are given as atemporal non-indicative; I have omitted the projective forms since it is the atemporal set that is of interest for the purposes of the present discussion.
} 
Table 6: Voice marking in Proto Malayo-Polynesian

\begin{tabular}{|c|c|c|c|c|c|}
\hline & & Actor voice & Patient voice & Location voice & $\begin{array}{l}\text { Circum- } \\
\text { stantial voice }\end{array}$ \\
\hline \multirow{3}{*}{$\begin{array}{l}\text { INDICATIVE } \\
\text { (INDEPENDE } \\
\text { NT) }\end{array}$} & Neutral & $\begin{array}{l}*<u m>\sqrt{ } \\
* k<u m>a R a ́ t\end{array}$ & $\begin{array}{l}* \sqrt{ } \text {-ən } \\
* \text { kaRat-əón }\end{array}$ & $\begin{array}{l}* \sqrt{ } \text {-an } \\
* \text { kaRat-án }\end{array}$ & $\begin{array}{l}*_{\mathrm{i}-\sqrt{ }} \\
*_{i-k a R a ́ t}\end{array}$ \\
\hline & Perfective & $\begin{array}{l}*<u m-i n>\sqrt{ } \\
* k<u m-i n>a R a ́ t\end{array}$ & $\begin{array}{l}* \text { *in }>\sqrt{ } \\
* k<i n>a R a ́ t\end{array}$ & $\begin{array}{l}* \text { *in }>\sqrt{ } \text {-an } \\
* k<i n>a R a t-a ́ n\end{array}$ & $\begin{array}{l}*_{i-\langle i n>\sqrt{ }} \\
*_{i-k<i n>a R a ́ t}\end{array}$ \\
\hline & Imperfective & $\begin{array}{l}*<u m>\operatorname{RED}-\sqrt{ } \\
* k<u m>a-k a R a ́ t\end{array}$ & $\begin{array}{l}\text { *RED- } \sqrt{ } \text {-ən } \\
\text { *ka-kaRat-ə́n }\end{array}$ & $\begin{array}{l}* \text { RED- } \sqrt{ } \text {-an } \\
* k a-k a R a t-a ́ n\end{array}$ & $\begin{array}{l}*_{\text {i-RED- }} \\
*_{i-k a-k a R a ́ t}\end{array}$ \\
\hline \multicolumn{2}{|c|}{$\begin{array}{l}\text { NON-INDICATIVE } \\
\text { (DEPENDENT) }\end{array}$} & $\begin{array}{l}* \sqrt{ } \\
* \text { kaRat }\end{array}$ & $\begin{array}{l}* \sqrt{-a} \\
* k a R a t-a\end{array}$ & $\begin{array}{l}* \sqrt{ }_{-\mathrm{i}} \\
* \text { kaRat }-\mathrm{i}\end{array}$ & $\begin{array}{l}* \sqrt{ } \text {-áni } \\
* \text { kaRat-ani }\end{array}$ \\
\hline
\end{tabular}

The transition from PMP to POc is characterized by a drastic simplification of the system laid out in 3.1 above. The whole paradigm of indicative forms in Table 6 was largely lost from the verbal system, although many forms are reflected in modern-day Oceanic languages with a nominalising function; this function is also reconstructed for the PMP forms. The non-indicative or dependent forms were then reanalyzed as independent, and the paradigm simplified: the patient voice suffix *-a was lost and its functions subsumed under the original locative voice suffix *-i. This form was then reanalyzed as a marker of transitivity on verbs, a function which reflexes of *-i show in a large number of present-day Oceanic languages (Evans 2003: 93). The merger and reanalysis is usually presented in the literature as a single change, but Næss (2013) points out that it involves two separate steps: Firstly, the loss of the independent forms and the concomitant reanalysis of the dependent forms as independent, the immediate outcome of which would have been a system contrasting an unmarked actor voice with an *-i-marked undergoer voice; and secondly, the reanalysis of this contrast as an intransitive-transitive distinction, where the PMP undergoer subject became the object of the reanalyzed construction. I have suggested elsewhere that Äiwoo reflects a stage where the first step had taken place, but not the second. I suggested above that the instances of overt actor-voice marking in Äiwoo represent an unproductive residue of earlier PMP voice morphology. This is a well-known outcome of processes of language change, where individual lexical items may retain morphology that has otherwise been lost; compare e.g. Scandinavian fossilized genitives in fixed expressions such as til skog-s ('into the forest'), til fjell-s ('to the mountains'), or remnants of the old -(e)n plural in English nouns like children and oxen. The productive pattern, however, would have contrasted an unmarked actor voice with an undergoer voice either marked by $*_{-i}$ or by taking clitics marking the undergoer argument directly; I have suggested that the latter may be the source of the undergoer-voice suffix - $(e) \hat{a}$, which may have been reanalyzed as an undergoervoice marker in order to provide explicit voice marking across the verbal lexicon.

At this stage, *-i would have had essentially the functions reconstructed by Evans (2003), namely causative and applicative, as long as "applicative" is taken to mean the function of introducing an additional patient-type argument to an intransitive stem, but not necessarily in "object" function. In addition, however, it functioned as an undergoer-voice marker on already transitive stems. As discussed in 4.6, these three functions - marking the undergoer voice, deriving an undergoer-voice transitive from an intransitive verb by introducing a new argument in VSA function, and forming causatives of some stative intransitive roots - are also attested for the Tagalog patient and locative voices. Notably, these are exactly the forms whose PMP sources are thought to have merged into POc *-i. If the source of Äiwoo - $i$ and -ive was a "regular" applicative, i.e. a derivational marker introducing an argument in nonsubject function, an extra 
step of reanalysis is required to account for how the present-day function of the Äiwoo morphemes arose. However, if $*_{-i}$ at the relevant stage functioned like the Tagalog patient and locative voices, it accounts straightforwardly for the Äiwoo facts; and the subsequent reanalysis of the voice contrast into a transitivity distinction then yields the system reflected in most present-day Oceanic languages. Admittedly, an unresolved puzzle is the proliferation of undergoer-voice forms in Äiwoo, and in particular the suffix -ive, for which no clear account is available at present.

To conclude, Äiwoo has a complex system of voice and valency marking which largely appears to reflect the functions reconstructed for POc $*_{i}$ and $*$ akin[i]. At the same time, Äiwoo appears to continue the "Philippine-type" voice system reconstructed for PMP, though with a much reduced system of voice alternations, and aspects of the Äiwoo system show quite detailed parallels to patterns found with the present-day Tagalog patient and locative voices, i.e. those forms for which their PMP sources are thought to have merged into POc *i. This suggests a more complex picture of the transition from PMP to POc than has generally been assumed, though this picture clearly needs filling in with more detail. One important step in providing such detail would be a detailed comparison between the Äiwoo system described here and those found in the languages of Santa Cruz; it is hoped that this paper can form the basis for further such comparative work.

\section{References}

Alfarano, Valentina. 2019. The applicative -neba in Nalögo: back to the origins. Conference presentation, APLL11, University of Leiden.

Arka, I Wayan. 2008. Voice and being core: Evidence from (eastern) Indonesian languages. In Voice and grammatical relations in Austronesian languages, ed. by Peter K. Austin and Simon Musgrave, 183-227. Stanford: CSLI.

Arms, David. 1973. Whence the Fijian transitive endings? Oceanic Linguistics 12, 503-558.

Ashley, Karen C. 2012. Semantics of Sa'a transitive suffixes and thematic consonants. MA thesis, Graduate Institute of Applied Linguistics.

Crowley, Terry. 2002. Serial verbs in Oceanic: a descriptive typology. Oxford: Oxford University Press.

Dixon, R.M.W. 1994. Ergativity. Cambridge: Cambridge University Press.

Evans, Bethwyn. 1995. Reconstructing object markers in Oceanic languages. Honours thesis, Australian National University.

Evans, Bethwyn. 2003. A study of valency-changing devices in Proto Oceanic. Canberra: Pacific Linguistics.

Foley, William A. 2008. The place of Philippine languages in a typology of voice systems. In Voice and grammatical relations in Austronesian languages, ed. by Peter K. Austin and Simon Musgrave, 22-44. Stanford: CSLI.

Hemmings, Charlotte. 2013. Causatives and applicatives: the case for polysemy in Javanese. SOAS Working Papers in Linguistics 16, 167-194. London: SOAS.

Hill, Deborah. 1992. Longgu grammar. PhD thesis, Australian National University.

Hill, Deborah. 1996. Loading canoes and loading coconuts: object alternation and verb class in Southeast Solomonic languages. Seminar handout. Canberra: Research School of Pacific and Asian Studies, Australian National University. 
Himmelmann, Nikolaus P. 2005a. The Austronesian languages of Asia and Madagascar: typological characteristics. In The Austronesian languages of Asia and Madagascar, ed. by Alexander Adelaar and Nikolaus P. Himmelmann, 110-181. London/New York: Routledge.

Himmelmann, Nikolaus P. 2005b. Tagalog. In The Austronesian languages of Asia and Madagascar, ed. by Alexander Adelaar and Nikolaus P. Himmelmann, 350-76. London/New York. Routledge.

Huang, Shuanfan, and Michael Tanangkingsing. 2011. A discourse explanation of the transitivity phenomena in Kavalan, Squliq, and Tsou. Oceanic Linguistics 50:93-119.

Kaufman, Daniel. 2009. Austronesian typology and the nominalist hypothesis. In Austronesian historical linguistics and culture history: a festschrift for Bob Blust, ed. by Alexander Adelaar and Andrew Pawley, 187-215. Canberra: Pacific Linguistics.

Kroeger, Paul. 1993. Phrase structure and grammatical relations in Tagalog. Stanford: CSLI. Lackey, William James, and Brenda H. Boerger, n.d. Re-examining the phonological history of Oceanic's Temotu branch. Unpublished manuscript.

Lichtenberk, Frantisek. 2001. On the morphological status of thematic consonants in two Oceanic languages. Issues in Austronesian morphology: A focusschrift for Byron W. Bender, ed. by Joel Bradshaw and Kenneth L. Rehg, 123-47. Canberra: Australian National University.

Lincoln, Peter C. 1978. Reefs-Santa Cruz as Austronesian. In Second International Conference on Austronesian Linguistics, ed. by Stephen A. Wurm and Lois Carrington, 929-967. Pacific Linguistics C-61. Canberra: The Australian National University.

Lynch, John, Malcolm Ross and Terry Crowley. 2002. The Oceanic languages. Richmond: Curzon.

Margetts, Anna. 1999. Valence and transitivity in Saliba, an Oceanic language of Papua New Guinea. (Max Planck Institute Series in Psycholinguistics Nijmegen, 12.) Nijmegen: Max Planck Institute for Psycholinguistics.

Naylor, Paz B. 1986. On the pragmatics of focus. In FOCAL I: Papers from the Fourth International Conference on Austronesian Linguistics, ed. by Paul Geraghty, Lois Carrington, and S. A. Wurm, 43-57. Canberra: Pacific Linguistics.

Næss, Åshild. 2006. Bound nominal elements in Äiwoo (Reefs): a reappraisal of the 'multiple noun class systems'. Oceanic Linguistics 45:2, 269-296.

Næss, Åshild. 2012. Cutting and breaking in Äiwoo: Event integration and the complexity of lexical expressions. Cognitive Linguistics 23: 2, 395-420.

Næss, Åshild. 2013. From Austronesian voice to Oceanic transitivity: Äiwoo as the "missing link". Oceanic Linguistics 52:1, 106-124.

Næss, Åshild. 2015a. Voice at the crossroads: symmetrical clause alternations in Äiwoo, Reef Islands, Solomon Islands. Oceanic Linguistics 54:1, 270-307.

Næss, Åshild. 2015b. The Äiwoo verb phrase: syntactic ergativity without pivots. Journal of Linguistics 51, 75-106.

Næss, Åshild. 2018. Standing up to the canoe: competing cognitive biases in the encoding of stative spatial relations in a language with a single spatial preposition. Cognitive Linguistics 29:4, 807-841.

Næss, Åshild, to appear. Äiwoo wâtu and the typology of comparatives. Studies in Language.

Næss, Åshild, and Brenda H. Boerger. 2008. Reefs-Santa Cruz as Oceanic: Evidence from the verb complex. Oceanic Linguistics 47: 1, 185-212. 
Pawley, Andrew. 1973. Some problems in Proto-Oceanic grammar. Oceanic Linguistics 12:1/2, $103-188$.

Peterson, David A. 2007. Applicative constructions. Oxford: Oxford University Press.

Riesberg, Sonja. 2014. Symmetrical voice and linking in Western Austronesian languages. Boston/Berlin: de Gruyter Mouton.

Ross, Malcolm. 2002. The history and transitivity of Western Austronesian voice and voicemarking. In Fay Wouk and Malcolm Ross (eds.), The history and typology of Western Austronesian voice systems, 17-62. Canberra: Pacific Linguistics.

Ross, Malcolm. 2018. Just how different was Proto Oceanic from Proto Malayo-Polynesian? Unpublished manuscript, Australian National University.

Ross, Malcolm and Åshild Næss. 2007. An Oceanic origin for Äiwoo, the language of the Reef Islands? Oceanic Linguistics 46: 2, 456-498.

Roversi, Giovanni. 2019. The morphosyntactic structure of the Äiwoo verb. MA thesis, University of Oslo.

Roversi, Giovanni, and Åshild Næss. 2019. Jespersen in the Reef Islands: single vs. bipartite negation in Äiwoo. Oceanic Linguistics 58:2, 324-352.

Schachter, Paul. 1976. The subject in Philippine languages: actor, topic, actor-topic, or none of the above? In Subject and topic, ed. by Charles Li, 491-518. New York: Academic Press.

Schachter, Paul. 1977. Reference-related and role-related properties of subjects. In Syntax and Semantics 8: Grammatical relations, ed. by Peter Cole and Jerrold Sadock, 279-306. New York: Academic Press.

van den Berg, René, and Brenda H. Boerger. 2001. A Proto-Oceanic passive? Evidence from Bola and Natügu. Oceanic Linguistics 50:1, 221-246.

Wurm, Stephen A. 1978. Reef-Santa Cruz: Austronesian, but ...! In Second International Conference on Austronesian Linguistics, ed. by Stephen A. Wurm and Lois Carrington, 969-1010. Pacific Linguistics C-61. Canberra: The Australian National University.

Wurm, Stephen A. 1981. Notes on nominal classification systems in Äiwo, Reef Islands, Solomon Islands. In Linguistics across continents: Studies in honor of Richard S. Pittman, ed. by Andrew Gonzalez and David Thomas, 123-142. Manila: Summer Institute of Linguistics/Linguistic Society of the Philippines.

Wurm, Stephen A. 1985. Language contact and special lexical developments. In Studia Linguistia Diachronica et Synchronica, ed. by Ursula Dieper and Gerhard Stickel, 961917. Berlin: Mouton de Gruyter.

Wurm, Stephen A. 1987. Semantics and world view in languages of the Santa Cruz Archipelago, Solomon Islands. In Language topics: essays in honor of Michael Halliday, ed. by Ross Steele and Terry Threadgold, 439-451. Amsterdam: John Benjamins.

Zúñiga, Fernando, and Seppo Kittilä. 2019. Grammatical voice. Cambridge: Cambridge University Press. 